Acta Universitatis Wratislaviensis • No 3869

Literatura i Kultura Popularna XXIV, Wrocław 2018

DOI: $10.19195 / 0867-7441.24 .21$

\author{
Adam Mazurkiewicz \\ ORCID: 0000-0003-3804-6445 \\ Uniwersytet Łódzki
}

\title{
O (możliwym) spojrzeniu na supersystem rozrywkowy $z$ perspektywy wykorzystania wybranych osiągnięć językoznawstwa. Propozycja metodologiczna
}

Słowa kluczowe: supersystem rozrywkowy, językoznawstwo, metodologia, kultura popularna

Keywords: supersystem of entertainment, linguistics, methodology, popular culture

Mianem „supersystemu rozrywkowego” będziemy określać — za Marshą Kinder — taki produkt kulturowy, który pojawia się w różnych mediach i istnieje dzięki funkcjonowaniu poszczególnych tekstów kultury w intertekstualnej i intermedialnej sieci powiązań. Jest on — jako całość — skonstruowany wokół konkretnej postaci lub grupy bohaterów, obecnych w różnych tekstach kultury ${ }^{1}$.

Pewną konfuzję może budzić sam termin będący kalką jednego z anglojęzycznych sformułowań, jakimi posługuje się sama badaczka w odniesieniu do analizowanego fenomenu. Należy przy tym brać pod uwagę fascynację reprezentantów humanistyki obserwowanym współcześnie „uobecnianiem się” danej opowieści w różnych mediach kultury (to jest fascynację tym, co zwykliśmy określać mianem transmedialności/transfikcjonalności) i — związany z owym zjawiskiem — rozwój teorii na temat warunków i przebiegu tego procesu, skutkujący

${ }^{1}$ Zob. M. Kinder, Playing with Power in Movies, Television, and Video Games. From Muppet Babies to Teenage Mutant Ninja Turtles, Berkeley 1993, s. 1, 122-123. Kinder zwraca uwagę (ibidem, s. 122), iż bohaterami „supersystemu rozrywkowego" mogą być zarówno postacie fikcyjne, jak i realnie istniejący idole popkultury (np. Beatlesi, Michael Jackson). Badaczka wskazuje też (ibidem, s. 4), że fenomen takiego „systemu” mógł powstać dopiero wówczas, gdy rozwój technologii pozwolił na wykorzystanie jej do tworzenia tekstów kultury. Gdyby nie różnorodność technologiczna, nie udałoby się odpowiednio skonsolidować tegoż „systemu”. 
powstaniem wielu, konkurencyjnych wobec siebie, interpretacji. Konsekwencją wytworzenia naukowej mody badania transmedialnych tekstów kultury jest chaos terminologiczny i funkcjonowanie wielu nieuzgodnionych (a najczęściej rozmytych znaczeniowo) terminów ${ }^{2}$. Niewykluczone, iż rozwiązaniem byłoby wprowadzenie nowego pojęcia operacyjnego, jednakże takie postępowanie stałoby w sprzeczności z zasadą brzytwy Ockhama, nakazującą nie mnożyć bytów ponad uzasadnioną konieczność badawczej akrybii.

Zatem na potrzeby niniejszego szkicu pozostaniemy przy zaproponowanym przez Kinder określeniu, świadomi jego wad i kontrowersji, jakie może ono budzić. Tym bardziej że na gruncie rodzimym termin „supersystem rozrywkowy” jest już przyswojony, nie tylko w krytyce literackiej oraz publicystyce, lecz także w pracach o charakterze stricte naukowym, których obiektem są różne zjawiska z kręgu popkultury (na przykład Piotr Sitarski omawia gotyckie nawiązania pojawiające się w Łowcy androidów [Blade Runner, reż. Ridley Scott, Honkgong-USA-Wielka Brytania], Zbigniew Wałaszewski pisze zaś o „Wiedźminie” jako o rodzimym supersystemie; z kolei Marek Gontarczyk wykorzystuje to pojęcie w refleksji politologicznej ${ }^{3}$ ).

Tym, co łączy przywołane tu wypowiedzi na temat supersystemów rozrywkowych, jest traktowanie ich jako fenomenu z pogranicza zjawisk kulturowych i rynkowych. Takie spojrzenie ma dość istotne konsekwencje metodologiczne, wymusza bowiem uwzględnienie w opisie nie tylko właściwości immanentnych danego przykładu, ale i kontekstu, w jakim on funkcjonuje. Inaczej mówiąc: namysłowi nad walorami artystycznymi towarzyszyć musi refleksja dotycząca kulturowo-społecznych uwarunkowań istnienia supersystemu w ramach określonej przestrzeni społecznej, w której pozostaje on zarazem odpowiedzią na zapotrzebowanie społeczne i czynnikiem modelującym ją. Owa samoświadomość metodologiczna jest tym istotniejsza, że — co podkreśla Leszek Skrzypek — stanowi warunek naukowości dyskursu ${ }^{4}$.

${ }^{2}$ Co więcej, wspomniane terminy bywają stosowane wymiennie, przy czym motywacją pozostaje kształt stylistyczny wywodu. Nie jest to zabieg właściwy, prowadzi bowiem do (najczęściej nieintencjonalnego) „pomieszania materii” wskutek przywoływania elementów różnych definicji. Walor stylistyczny wykorzystywania różnych terminów w funkcji synonimicznej powinien ustąpić przed wymogami precyzji terminologicznej — nie tylko zresztą w pracach stricte naukowych, lecz także w publicystyce.

${ }^{3}$ Zob. P. Sitarski, Obcość i dekoracje w systemie rozrywkowym „Blade Runner”, [w:] Wokót gotycyzmów. Wyobraźnia, groza, okrucieństwo, red. G. Gazda, A. Izdebska, J. Płuciennik, Kraków 2002; Z. Wałaszewski, Wiedźmin: pierwszy polski supersystem rozrywkowy, [w:] Obraz literatury w komunikacji społecznej po roku '89, red. A. Werner, T. Żukowski, Warszawa 2013; M. Gontarczyk, Obama i McCain z mieczami świetlnymi, czyli politycy $w$ dobie kulturowej konwergencji, „e-Politikon” 2013, nr 5, http://oapuw.pl/wp-content/uploads/2013/08/Gontarczyk-M..pdf (dostęp: 24.11.2017).

${ }^{4}$ Zob. L. Skrzypek, Humanista w poszukiwaniu metody, „Scripta Comeniana Lesnensia” 2008, nr 6, s. 52, http://www.wydawnictwa.pwsz.edu.pl/files/SCL/nr_6/051-058_Skrzypek.pdf(dostęp: 24.11.2017). 
Pozornie dobór instrumentarium badawczego wydaje się łatwy: za najbardziej adekwatne należałoby uznać studia kulturowe. To one bowiem — łącząc w sobie elementy różnych, funkcjonujących w przestrzeni społecznej, dyskursów (między innymi postkolonializmu, women studies, studiów feministycznych i posthumanistycznych) — stają się, powtórzmy za Josephem Natolim, dyskursem, którego celem jest interpretowanie innych dyskursów ${ }^{5}$. Tym jednak, co nakazuje badaczowi akcentować wątki związane $\mathrm{z}$ autorefleksją języka opisu naukowego, pozostaje znamienne dla cultural criticism wykorzystanie „metodologicznego bricolage'u” (określenie Cary'ego Nelsona, Pauli A. Treichler i Lawrence'a Grossberga); najrozmaitsze zdobycze dwudziestowiecznej humanistyki — między innymi analiza fonemiczna, dekonstrukcja, psychoanaliza - są w tym nurcie traktowane instrumentalnie ze względu na użyteczność w danym przypadku, nie zaś jako pełnowartościowe metodologie, z których każda mogłaby zostać wykorzystana do badania tekstu kultury ${ }^{6}$.

Przeniesienie w studiach kulturowych akcentu uwagi z tekstu na kontekst, w jakim ów tekst funkcjonuje, sprawia jednak, że w centrum wywodu pojawia się język opisu, nie zaś jego przedmiot; ten bowiem coraz częściej zostaje potraktowany jako pre tekst do snucia (meta)teoretycznych refleksji. Tym samym — paradoksalnie — z pola zainteresowania badawczego znika zjawisko będące obiektem analiz; namysł nad nim zastępuje refleksja nad różnorodnymi uwarunkowaniami mającymi wpływ na jego funkcjonowanie w kulturze.

Owszem, badania kulturowe pozostają cennym dowodem świadomości metodologicznej i jej uwikłań w dyskursy istniejące w społeczeństwie. W tym zakresie nie sposób przecenić walorów poznawczych omawianego nurtu; prace na nim oparte dokumentują bowiem procedurę badawczą zastosowaną do rozwoju narzędzi, dzięki którym możliwe stają się nowe odczytania i reinterpretacja dotychczasowych ustaleń ${ }^{7}$. Jednakże — zgodnie przecież z wytycznymi metodologicznymi

${ }^{5}$ Zob. J. Natoli, Introduction, [w:] Tracing Literary Theory, red. J. Natoli, Urbana 1987, s. 10. Exemplum interesującym pod opisanym względem pozostaje praca V.B. Leitcha Cultural Criticism, Literary Theory, Poststructuralism (New York 1992) intencjonalnie poświęcona badaniom kulturowym. Nie zabrakło w niej uwag m.in. na temat teorii postkolonialnej traktowanej jako element tych badań (ibidem, s. 94-99). Na gruncie nauki polskiej w podobny sposób kulturową teorię literatury definiowała Anna Burzyńska, zwracając uwagę na rangę kontekstów interpretacyjnych (Kulturowy zwrot teorii, [w:] Kulturowa teoria literatury. Główne pojęcia i problemy, red. M.P. Markowski, R. Nycz, Kraków 2010, s. 79).

${ }^{6}$ Zob. C. Nelson, P.A. Treichler, L. Grossberg, Cultural Studies: An Introduction, [w:] Cultural Studies, red. C. Nelson, P.A. Treichler, L. Grossberg, New York 1992, s. 2. Opisywane przez badaczy zjawisko łączenia wiedzy z kręgu różnych dyscyplin można uznać za właściwe dla procesów zachodzących we współczesnej humanistyce, w której tendencjom do antropologizacji dyskursu towarzyszą procesy „konwergencji dyscyplin” (A. Hejmej, Komparatystyka interdyscyplinarna, [w:] Komparatystyka dla humanistów. Podręcznik akademicki, red. M. Dąbrowski, Warszawa 2011, s. 89).

7 Zob. J. Apanowicz, Metodologia ogólna, Gdynia 2002, s. 20. Przypomnijmy, iż J.M. Bocheński (Wspótczesne metody myślenia, Poznań 1992, s. 20-21) definiował metodologię jako 
— przed przystąpieniem do analiz trzeba dookreślić ich przedmiot: czy jest nim zjawisko/tekst kultury (oraz jego funkcjonowanie w popkulturze), czy też sposób jego opisu? Od odpowiedzi na to pytanie zależy bowiem nie tylko rozłożenie akcentów uwagi, lecz także dobór instrumentarium badawczego.

Naszkicowany tu problem w odniesieniu do supersystemu rozrywkowego traktowanego jako zjawisko kulturowe ewokuje kolejną kwestię: przeniesienia terminologii właściwej naukom spoza kręgu humanistyki (głównie z ekonomii i teorii komunikacji) na grunt opisu zjawiska kulturowego. Owszem, terminologia ta bywa niezbędna zwłaszcza do prezentacji funkcjonowania „supersystemu” w imaginarium communis; łatwo jednak wówczas zatracić perspektywę. Owo niebezpieczeństwo łączy się z symptomatycznym charakterem supersystemu rozrywkowego, to jest $\mathrm{z}$ wzajemnym powiązaniem dużej liczby jego cech i właściwości, uniemożliwiającym abstrahowanie od którejkolwiek z nich; w efekcie konieczne staje się rozpatrywanie owych cech całościowo poprzez odwołanie się do ujęcia interdyscyplinarnego ${ }^{8}$.

Do pewnego stopnia w sukurs badaczowi przychodzą tu dwie metodologie, ugruntowane tradycją studiów humanistycznych: krytyka retoryczna i metoda filologiczna. Ich walor wynika - co akcentuje Jakub Z. Lichański - z respektowania immanentnych właściwości tekstu (przede wszystkim literackiego, lecz — szerzej — również kultury ${ }^{9}$. Innymi słowy, wskazane przez uczonego metody jako jedyne koncentrują się na tekście, nie zaś na towarzyszących mu okolicznościach (w najbardziej wszechstronnym rozumieniu tego pojęcia).

Owszem, w odniesieniu do tak intermedialnego zjawiska, jakim są supersystemy rozrywkowe, przydatność badań tekstu, z pominięciem (lub traktowaniem jako sekundarnych) uwikłań owego tekstu w konteksty (rynkowe, technologiczne, medialne etc.) może wydawać się ograniczona. Wynika to z samej koncepcji takiego supersystemu, w którym — w myśl supozycji Sitarskiego, omawiającego wywody Kinder - aspekt ekonomiczny współistnieje z estetycznym i oba te aspekty wzajemnie się stymulują ${ }^{10}$. Zamiast jednak rezygnować z metod „tekstocentrycznych" na rzecz badań kulturowych, spróbujmy poszukać narzędzi opisu równie co w przypadku metody filologicznej i rhetorical criticism skoncentrowanych na omawianym zjawisku. Zaproponowane tu stanowisko może wydać się nazbyt redukcjonistyczne, zwłaszcza w kontekście rozpatrywanej przez Sitarskiego ekonomiczno-artystycznej specyfiki supersystemu rozrywkowego. Zarazem

namysł nad teorią metody. Wynika z tego, że dla każdej metody można sformułować właściwą jej metodologię.

${ }^{8}$ Zob. S. Stachak, Wstęp do metodologii nauk ekonomicznych, Warszawa 1997, s. 39.

${ }^{9}$ Zob. J.Z. Lichański, ,, Ty jesteś moja świattość świata...”. „, Niobe” Konstantego Ildefonsa Gatczyńskiego, Kraków 2015, s. 57-58, 74, 105-106. Nie jest to propozycja stanowiąca w wypadku Lichańskiego metodologiczne novum, jednakże w najnowszej pracy została ukazana w sposób, który można uznać za propedeutykę do metody filologicznej. Z tego powodu monografia poematu Gałczyńskiego zajmuje szczególne miejsce w dorobku naukowym badacza.

${ }^{10}$ Zob. P. Sitarski, op. cit., s. 180. 
jednak takie podejście, jak sugerowane tu, pozwala na ,powrót do tekstu” - poprzez usytuowanie go w punkcie centralnym namysłu badawczego.

Pewną propozycję, wartą pogłębionej refleksji, zdają się oferować metody badań językoznawczych, inspirowane założeniami opisu gniazdowego (w leksykologii i psycholingwistyce) oraz semantyki interpretacyjnej ${ }^{11}$. Jako punkt wyjścia do zastanowienia się nad ich potencjalnymi zaletami potraktujmy spostrzeżenie Louisa Trolle Hjelmsleva na temat swoistej „uniwersalności” badań językoznawczych:

Wydaje się celowe i konieczne ustalenie wspólnego punktu widzenia dla przedstawicieli licznych dyscyplin — poczynając od badań nad literaturą, sztuką, muzyką i od historii powszechnej, a kończąc na logice i matematyce - po to, żeby, patrząc na te nauki z owego wspólnego punktu widzenia, mogli [oni] się skupić wokół problemów sformułowanych w sposób językoznawczy ${ }^{12}$.

Już teraz jednak uczyńmy konieczne zastrzeżenie: nie chodzi o proste nałożenie terminologii związanej z badaniem „supersystemów rozrywkowych” na siatkę inspirowaną supozycjami językoznawczej metody badań gniazdowych. Opisywane za pomocą tych supozycji procesy mają stanowić punkt odniesienia umożliwiający stworzenie analogii pomiędzy zjawiskami językowymi a tymi, które zachodzą w ramach supersystemu rozrywkowego. Aby jednak postępowanie takie uczynić możliwym, należy założyć, że supersystem rozrywkowy funkcjonuje na wzór pojęcia systemu i struktur głębokich w językoznawstwie. Stąd badanie specyfiki danego supersystemu będzie zbliżone (tożsame?) z namysłem nad podstawowymi relacjami, w jakie wchodzą elementy tegoż supersystemu; nieprzypadkowo Algirdas J. Greimas definiuje strukturę jako sposób istnienia znaczenia przez występowanie relacji poszczególnych składników tej struktury ${ }^{13}$. Badacz niejako implicite zakłada więc doniosłość związków, w jakie owe składniki — czyli w naszym wypadku teksty kultury — wchodzą względem siebie zarówno w sposób bezpośredni (to jest w sytuacji, gdy w jednym tekście pojawiają

11 To zresztą tylko jedna z możliwości. Inną — zaproponowaną przez prof. Mariusza Kraskę w dyskusji nad referatem z niniejszego artykułu — jest koncepcja „genologii multimedialnej” E. Balcerzana (W stronę genologii multimedialnej, „Teksty Drugie” 1999, nr 6). Ma ona — w myśl autorskich intencji uczonego - eksponować pokrewieństwo tekstów kultury różniących się między sobą pod względem tworzywa. Utożsamienie ,genologii multimedialnej” z namysłem nad normami „gier znaków i form” (określenie Balcerzana - ibidem, s. 23) istotnie wydaje się szczególnie adekwatne do badania zjawisk, które — niczym supersystemy rozrywkowe - uobecniane są w wielu mediach. Należy jednak mieć świadomość - o czym sam Balcerzan pisze po latach (Sobowtóry i refleksy literackości w uniwersum semiotycznym, [w:] idem, Literackość. Modele, gradacje, eksperymenty, Toruń 2013, s. 410) — polisemiczności terminu „multimedia”, który w ostatnim czasie stał się modny, a tym samym nadużywany do tego stopnia, że jego zakres znaczeniowy uległ rozmyciu.

12 L.T. Hjelmslev, Prolegomena do teorii języka, przeł. H. Kurkowska, A. Weinsberg, [w:] Językoznawstwo struktura;ne. Antropologia tekstów, red. H. Kurkowska, A. Weinsberg, Warszawa 1979, s. 116.

13 Zob. A.J. Greimas, Semantique structurale. Recherche de methode, Paris 1966, s. 28, cyt. za: K. Rosner, A.J. Greimasa semiotyka narracji, „Pamiętnik Literacki” 1976, z. 2, s. 342. 
się postacie bądź zdarzenia odsyłające odbiorcę do innego tekstu), jak i pośredni (czyli wówczas, kiedy naddane sensy wypływają ze znajomości tekstów tworzących kulturowy „kanon” danego supersystemu ${ }^{14}$ ). Dopiero bowiem znaczenie generowane przez całość tekstów i relacji między nimi współkreuje „supersystem rozrywkowy" w rozumieniu zaproponowanym przez Kinder.

Taka koncepcja może budzić poważne zastrzeżenia natury metodologicznej; inne są przecież oferowane użytkownikowi danego języka (wraz z jego naturalnym bogactwem form i reprezentacji) sposoby rekombinacji elementów współtworzących go, inne zaś dotyczą ograniczonego (najczęściej do niewielu mediów, głównie o charakterze audiowizualnym) supersystemu rozrywkowego. Zmiana ta ma jednakże charakter ilościowy, nie jakościowy. Wygląda zatem na to, że w obu przypadkach można wykorzystać mechanizm odpowiedzialny za krystalizowanie się wspomnianych relacji charakteryzujących strukturę głęboką — w odniesieniu zarówno do języka, jak i do supersystemu rozrywkowego. Tak też zdaje się rozumieć podobieństwo języka i kultury (oraz jej wytworów) Wojciech J. Burszta wskazujący na uniwersalistyczny charakter koncepcji strukturalno-semiotycznej etnologów czerpiących zarówno z myśli Claude'a Levi-Straussa, jak i z gramatyki transformacyjno-generatywnej Noama Chomsky'ego. Uniwersalizm ten - co podkreśla Burszta - zawiera się w tożsamości reguł języka i kultury (a zatem i jej produktów) na najbardziej elementarnym poziomie, co z kolei umożliwia stosowanie (w odniesieniu do języka i kultury) tych samych założeń teoretyczno-metodologicznych ${ }^{15}$.

Aby jednak wspomniane wykorzystanie stało się możliwe, niezbędne jest dookreślenie związków, jakie zachodzą pomiędzy „supersystemem rozrywkowym” a terminami rudymentarnymi dla językoznawczej myśli strukturalistycznej, takimi jak ,znak”, ,język”, „struktura” oraz „system”16. Z tego względu nieod-

14 Osobną kwestią pozostaje konieczność znajomości „tekstów pobocznych” (przede wszystkim fan fiction) przez miłośnika konkretnego supersystemu. Niewątpliwie wzbogacają one jego wiedzę o zdarzeniach fabularnych i o bohaterach opowieści uobecnianej w wielu mediach, lecz zarazem owa wiedza nie wpływa na reinterpretację całości supersystemu. Sytuację tę może zmienić „wejście” danego wytworu kultury fanowskiej do „kanonu” — wówczas znajomość tegoż produktu staje się nieodzowna. W tym wypadku jednakże przekształceniu ulega także status tekstu i relacje, w jakich pozostaje on wobec innych w ramach określonego „supersystemu rozrywkowego". Przykładem służą dodatki, którym nadano status oficjalnych, jak choćby Uczta lodu i ognia (A Feast of Ice and Fire, 2012, pol. 2013) Ch. Monroe-Cassel i S. Lehrer - zbiór przepisów kulinarnych adresowanych do miłośników „Pieśni Lodu i Ognia” („A Song of Ice and Fire”, 1996-, pol. 1998-) G.R.R. Martina - lecz także fanowskie thumaczenia dialogów w serialu Ghost in the Shell: Stand Alone Complex (reż. K. Kamiyama, Japonia 2002-2005), dołączane do wydań DVD jako alternatywna wersja napisów.

15 Zob. W.J. Burszta, Język a kultura w myśli etnologicznej, Wrocław 1986, s. 8, 92-95.

${ }^{16}$ Dziękuję prof. Mariuszowi Krasce za zwrócenie uwagi na tę kwestię w dyskusji wokół referatu z niniejszego artykułu. Podnoszone przez niego (podobnie jak przez dr. hab. Konrada Dominasa) wątpliwości w poważny sposób przyczyniły się do modyfikacji pierwotnej koncepcji przedstawionej w referacie. 
zowne okazuje się stworzenie słownika definicji operacyjnych pozwalających na doprecyzowanie zakresu redefinicji owych terminów przejętych z wiedzy o języku. Konieczne jest przy tym jednakże zachowanie szczególnej ostrożności, gdyż - co uzmysławia lektura szkicu Moniki Banaś, poświęconego konsekwencjom „dyfuzji terminologicznej” — podczas nakładania się na siebie terminologii inspirowanej różnymi dyscyplinami naukowymi dochodzi nie tylko do nieporozumień, lecz także do mistyfikacji i zafałszowań (czy intencjonalnych to kwestia osobna, należąca do sfery etyki badań naukowych) ${ }^{17}$.

Alternatywą dla postulowanego tu tworzenia słownika definicji może stać się namysł, do jakiego stopnia da się wykorzystać założenia instrumentarium językoznawczego do badania różnorodnych (z uwagi na tworzywo) zjawisk kulturowych. Traktowane byłyby one w tym ujęciu - na wzór semiotycznego jako znaki, definiowane przez Jurija Łotmana jako ekwiwalent przedmiotów, które zostają zastępowane innymi przedmiotami w procesie wymiany informacji $\mathrm{w}$ zbiorowości ${ }^{18}$. Znaki te są wewnętrznie zróżnicowane pod względem struktury, o czym przekonuje Władimir A. Zariecki. Według niego jednostkową informację może - z punktu widzenia cybernetycznej natury mowy — przenosić nie tylko pojedyncza litera/fonem, lecz także cały leksem ${ }^{19}$.

W celu zobrazowania tego zjawiska warto odwołać się do koncepcji Hjelmsleva, traktującego znak językowy właśnie jako strukturę ${ }^{20}$. Jest ona (w myśl dokonanego przez Katarzynę Rosner odczytania koncepcji językoznawcy) złożona podwójnie, na planie językowej ekspresji współtworzy ją bowiem zespół fonemów, a na planie zawartości - mniejsze jednostki sensu; z tego względu analiza powinna obejmować oba plany, prowadząc do rozpoznania jednostek elementarnych ${ }^{21}$. W przypadku supersystemów rozrywkowych analogami owych jednostek elementarnych, o których pisze Rosner, komentując myśl Hjelmsleva,

17 Zob. M. Banaś, Transgresja i dyfuzja - czyli o tym, dlaczego nauki społeczne i humanistyczne siegaja do terminologii nauk przyrodniczych, „Kultura - Historia — Globalizacja” 2013, nr 14, s. 7-8, http://www.khg.uni.wroc.pl/files/1_\%20KHG_14_banas_t.pdf (dostęp: 19.11.2016).

18 Zob. J. Łotman, Semiotyka filmu, przeł. J. Faryno, T. Miczka, Warszawa 1983, s. 12.

19 Zob. W.A. Zariecki, Obraz jako informacja, przeł. L. Suchanek, „Pamiętnik Literacki” 1969 , z. 1, s. 260.

${ }^{20}$ Zob. L. Hjelmslev, op. cit., s. 74. Badacz deklaruje wprost: „Języków nie można [...] opisywać jako czystych systemów znakowych. Ze względu na cel im przypisywany są one przede wszystkim systemami znaków, ale ze względu na swoją wewnętrzną budowę są przede wszystkim czym innym, a mianowicie systemami figur, których można użyć do budowy znaków" (ibidem). Myśl ta zostaje doprecyzowana w innej pracy — Sproget. En Introduktion (Kopenhaga 1963) — w której Hjelmslev kładzie nacisk na konieczność uznania danej struktury za język, jeśli jej człony kategorialne są wzajemnie wymienne. Zob. idem, Jazyk, przeł. M. Dokulil, Praha 1971, s. 93: „Můžeme $v$ stručnosti definovat jazyk jako strukturu, jejiž kategorijni členy jsou nawzajem vyměnitelné”.

${ }^{21}$ Zob. K. Rosner, Semiotyka strukturalna w badaniach nad literatura. Jej osiagnięcia, perspektywy i ograniczenia, Kraków 1981, s. 107. 
pozostają teksty kultury współkreujące dany supersystem rozrywkowy ${ }^{22}$. Wchodzą one między sobą w następujące relacje charakterystyczne dla znaków językowych: przemieszczenie, tworzenie przez analogię, skracanie ${ }^{23}$.

Zaproponowane tu wzajemne naświetlanie problemów językoznawstwa i semiotyki prowadzi do traktowania języka przez pryzmat teorii powstawania znaków i teorii znaku; jest to możliwe, gdyż — w myśl supozycji Tomasza Nowaka - lingwistyka jako nauka czerpie z semiotyki, traktowanej przez badacza jako dział filozofii ${ }^{24}$. Co więcej, w pracach reprezentantów szkoły tartusko-moskiewskiej semiotyka była postrzegana właśnie jako nauka o języku tożsamym z systemem znaków ${ }^{25}$. Znaki te oczywiście podlegają translacji, która może prowadzić do nieokreśloności semantycznej. Przekład z jednego języka (resp. systemu znaków, na przykład literatury, filmu, komiksu) na inny prowadzi do wariacyjności rozwiązań artystycznych ${ }^{26}$. Uzyskana dzięki nim wartość naddana tworzy

22 Być może zaproponowana tu analogia wydaje się nazbyt odległa, niemniej należy pamiętać o możliwości odczytywania myśli L. Hjelmsleva przez pryzmat postulatu semiotyków, według którego przedmiotem ich dyscypliny pozostaje każda struktura analogiczna do języka (rozumianego jako system figur) pod względem formalnym (zob. idem, Prolegomena..., s. 134). Kierując się tą wskazówką, wolno wykorzystać rozważania badacza - jak zresztą czyni E. Krupińska $(C z y$ Hjelmsleva można zastosować w muzykologii? Substancjalno-formalna analiza dzieła muzycznego - preliminaria, „Res Facta Nova” 2012, nr 13, http://www.resfactanova.pl/pliki/archiwum/ numer_22/RFN22\%20Krupinska\%20-\%20Czy\%20Hjelmsleva\%20mozna\%20zastosowac\%20 w\%20muzykologii.pdf (dostęp: 24.11.2017); Jak Hjelmsleva można zastosować w muzykologii? Analiza substancjalno-formalna dzieła operowego na przykładzie opery „Faustus, the Last Night” (2003-2004) Pascala Dusapina, ,Res Facta Nova” 2013, nr 14, http://www.resfactanova.pl/pliki/ archiwum/numer_23/RFN23\%20Krupinska\%20-\%20Jak\%20Hjelmsleva\%20mozna\%20zastosowac\%20w\%20muzykologii.pdf (dostęp: 24.11.2017) — do ustaleń muzykologii.

${ }^{23}$ Zob. L. Hjelmslev, Jazyk..., s. 43-57. Szczegółowe omówienie strategii wykorzystywanych przez twórców „supersystemów rozrywkowych” (na przykładzie „supersystemu rozrywkowego" „Metro 2033”), dokonane przez pryzmat wyróżnionych przez Hjelmsleva relacji znaków językowych względem siebie — zob. aneks do niniejszego artykułu.

${ }^{24}$ Zob. T. Nowak, Język w świetle odkryć nauki, Kraków 2011, s. 21. Na temat możliwych pograniczy językoznawstwa i innych dyscyplin naukowych zob. A. Furdal, Językoznawstwo otwarte, Opole 1977, s. 30-31, 38-41; Z. Wąsik, Semiotyczny paradygmat językoznawstwa. Z zagadnień metodologicznego statusu lingwistycznych teorii znaku i znaczenia, Wrocław 1987, s. 87-95. Jako punkt odniesienia dla propozycji obu przywołanych tu badaczy wolno potraktować uwagi M. Ossowskiej i S. Ossowskiego (Nauka o nauce, „Nauka Polska” 20 [1935]; M. Ossowska, Nauka o nauce, [w:] eadem, O człowieku, moralności i nauce. Miscellanea, Warszawa 1983, s. 269, cyt. za: Z. Wąsik, op. cit., s. 144-145) na temat możliwych powinowactw między dyscyplinami naukowymi: „Łącznikiem pomiędzy zagadnieniami jakiejś nauki niekoniecznie ma być jedność metod i punktów widzenia. Łącznikiem takim może być przedmiot stanowiący ośrodek zainteresowań; przy czym nie znaczy to wcale, aby ten przedmiot miał być jedynym przedmiotem badań danej nauki; mamy prawo mówić o jedności przedmiotu i wówczas, gdy bada się różnorodne przedmioty, jeżeli tylko stały się one przedmiotem badania ze względu na ów wspólny ośrodek zainteresowań".

25 Zob. J. Łotman, Szuka jako język, [w:] idem, Struktura tekstu artystycznego, przeł. A. Tanalska, Warszawa 1984, s. 18-19.

${ }^{26}$ Z perspektywy semantycznej taką „,kulturową translację znaku” omawia J. Łotman w książce Kultura i eksplozja. przeł. i wstęp B. Żyłko, Warszawa 1999, s. 33-34. 
dany supersystem rozrywkowy, jej usunięcie spowodowałoby zaś rozpad takiego systemu. W języku analogiczny proces „naddawania” wartości da się zauważyć w sferze frazeologizmów, których sensu nie sposób sprowadzić do sumy znaczeń poszczególnych składowych wyrażenia ${ }^{27}$. Dzięki tej prawidłowości frazeologizm — zwłaszcza jeśli odwołuje się do świadomości potocznej — odzwierciedla codzienne doświadczenie użytkownika nawet wówczas, gdy poszczególne jego elementy przestają należeć do rzeczywistości obiektywnej ${ }^{28}$.

Przy poszukiwaniu ,powinowactw z wyboru” między metodologiami właściwymi językoznawstwu a zjawiskami kultury — w tym wypadku supersystemami rozrywkowymi — trzeba jednak zachować daleko posuniętą ostrożność, łatwo tu bowiem o nadużycia interpretacyjne. Mogą one być konsekwencją swoistego charakteru sztuki jako - posłużmy się sformułowaniem Łotmana - systemu wtórnego. W nim zaś denotaty mają charakter wtórny wobec systemu pierwotnego (czyli języka) i stanowią jego model, nie zaś kopię ${ }^{29}$. Na wspominane tu nadużycia szczególnie narażona jest przejęta terminologia, która powinna być dostosowywana pod względem zakresu semantycznego do nowego kontekstu ${ }^{30}$. Co więcej, jej redefinicja musi uwzględniać także kontekst pierwotny, w nim bowiem pozostaje ugruntowana tradycją badawczą; tym samym dowolne modyfikowanie terminów nierzadko prowadzi do nieporozumień.

Jest to zresztą aktualizacja szerszego zagadnienia: zakresu uprawnionej analogii między dwoma różnymi jakościowo zjawiskami kulturowymi. Toteż, jakkolwiek możliwe byłoby odnalezienie paralel między założeniami językoznawstwa inspirowanego głównymi tezami strukturalizmu a mechanizmami regulującymi funkcjonowanie supersystemu rozrywkowego, niewykluczone, że takie podobieństwo będzie powierzchowne lub że będziemy mieć do czynienia nie tyle $\mathrm{z}$, powinowactwami z wyboru”, ile z koincydencją mechanizmów za nie odpowiedzialnych. $Z$ tego względu nie należy traktować opisu intermedialnych i intertekstualnych odniesień właściwych poszczególnym elementom „supersystemu rozrywkowego" jako pełnego analogu, na przykład siatki relacji motywacyjnej

${ }^{27}$ Zob. S. Bąba, Twardy orzech do zgryzienia, czyli O poprawności frazeologicznej, Poznań 1986, s. 10-11.

${ }^{28}$ Zob. J. Warchala, Kategoria potoczności w języku, Katowice 2003, s. 32.

${ }^{29}$ Zob. J. Łotman, O znaczeniach we wtórnych systemach modelujacych, przeł. J. Faryno, „Pamiętnik Literacki” 1969, z. 1, s. 292. Sekundarny charakter sztuki jako języka wobec języka naturalnego wyjaśnia Łotman (Sztuka jako język..., s. 19) następująco: „Ponieważ świadomość człowieka jest świadomością językową, wszystkie postaci nadbudowanych nad świadomością modeli — w tej liczbie także sztuka — mogą być określone jako wtórne systemy modelujące".

${ }^{30}$ Mamy zresztą w takiej sytuacji do czynienia ze zjawiskiem analogicznym do znanej z językoznawstwa tzw. hipotezy zerowej, zwłaszcza jeśli sytuacja ta przybiera postać: „mechanizm zjawiska $x$ jest taki sam jak zjawiska $y$ " (J. Linde-Usiekniewicz, Semantyka strukturalna w XXI wieku?, [w:] Metodologie językoznawstwa. Wspótczesne tendencje i kontrowersje, red. P. Stalmaszczyk, Kraków 2008, s. 167). 
między wyrazami wobec całości zbioru słownikowego w opisie gniazdowym ${ }^{31}$. Trudno też utożsamiać funkcjonalnie gniazdo leksemu z ,archetekstem” stojącym u podstaw supersystemu rozrywkowego, a derywaty i łańcuchy słowotwórcze - z tekstami rozbudowującymi ów supersystem ${ }^{32}$. Wiele zastrzeżeń budzi również poszukiwanie zbieżności pomiędzy kulturowymi zjawiskami w obrębie supersystemu (na przykład nowelizacją, gamifikacją, ekranizacją zarówno utworu literackiego, jak i tekstu kultury powstałego na podstawie tego utworu) a paradygmatem słowotwórczym ${ }^{33}$.

Taka analogia pozostaje ułomna, gdyż w supersystemie rozrywkowym „rdzeniem" nie musi być podstawowy, organizujący go tekst kultury. W ramach tegoż supersystemu nie może też być mowy o tym, co w myśl propozycji Sebastiana Konstantynowicza Szaumiana znajduje się u źródeł modelu generatywnego tworzenia wyrazów, to jest o „amorficznym słowie pierwotnym” (амо́рфное слоьо-ко́рень $)^{34}$. Zawsze bowiem da się wskazać tekst założycielski będący „archetekstem” danego „supersystemu rozrywkowego”. Nawet jeśli bowiem — jak w przypadku multimedialnego projektu franczyzowego .hack// (2002-) - poszczególne teksty w różnych mediach uzupełniają się wzajemnie, dopiero razem stanowiąc spójną fabularnie całość, możliwe jest zidentyfikowanie utworu chronologicznie najwcześniejszego ${ }^{35}$. Ponadto trudno o takie, jak zasygnalizowane powyżej, zabiegi zmierzające do wyprowadzenia pełnej analogii pomiędzy zjawiskami opisywanymi przy użyciu kategorii właściwych słowotwórstwu gniazdowemu, z uwagi na immanentne właściwości języka jako polisemicznego kodu tekstotwórczego, którego skomplikowanie przekracza potencjał autorów supersy-

${ }^{31}$ Zob. H. Jadacka, Opis gniazdowy jako podstawa badania taczliwości formantów, „Prace Filologiczne" 43, 1998; M. Skarżyński, Stan obecny i perspektywy słowotwórstwa synchronicznego, [w:] Collectanea linguistica. In honorem Casimiri Polański, red. M. Brzezina, H. Kurek, Kraków 1999, s. 206.

32 Przypomnijmy najbardziej elementarną definicję słowotwórstwa gniazdowego: ,[jest ono] nakierowane na badania obiektów większych — grup derywatów skupionych wokół jednego niemotywowanego słowotwórczo leksemu, będącego ich bezpośrednią lub pośrednią bazą derywacyjną, dla którego przyjęto nazwę "gniazda słowotwórcze«. [...] derywacja jest wielostopniowa (gradualna), a stosunki motywacyjne wiążą się ze sobą nie tylko w pary wyrazowe, ale właśnie całe duże, a czasem bardzo duże, bo liczące i kilkaset wyrazów, grupy" (M. Skarżyński, Wstęp, [w:] Stowotwórstwo gniazdowe. Historia, metoda, zastosowania, red. M. Skarżyński, Kraków 2003, s. 7). Na temat rozumienia terminu „słowotwórstwo gniazdowe" (wraz z rysem historycznym tej koncepcji) zob. M. Olejniczak, 30 lat stowotwórstwa gniazdowego (rys historyczny), [w:] Stowotwórstwo gniazdowe...

${ }^{33}$ Za Iwoną Burkacką (Porównawcza analiza gniazdowa wybranych leksemów neutralnych $i$ nacechowanych ekspresywnie, Warszawa 2001, s. 16) mianem tym będziemy (w odniesieniu do zagadnień językoznawczych) określać zbiór derywatów znajdujących się na jednym takcie derywacyjnym i mających wspólny wyraz motywujący.

34 Zob. S.K. Szaumian, Структурная лингвистика, Moskwa 1965, s. 15.

35 Zob. http://www.hack.channel.or.jp (dostęp: 8.06.2016). Jest to zresztą właściwość supersystemu rozrywkowego, w którym, co podkreśla P. Sitarski (op. cit., s. 180), relacje chronologiczne poszczególnych współtworzących go tekstów kultury ulegają zatarciu. 
stemu rozrywkowego. Ten bowiem ogranicza się do konkretnej liczby komponentów zróżnicowanych medialnie.

Zarazem jednak trudno oprzeć się wrażeniu, że mechanizmy opisywane przez słowotwórstwo gniazdowe pozwalają na prześledzenie pochodzenia danego elementu supersystemu rozrywkowego w jego relacji nie tylko do ,archetekstu” założycielskiego, lecz także do rozbudowujących go tekstów kultury. Naszkicowana tu prawidłowość implikuje systemowy charakter języka, właściwy myśleniu strukturalistycznemu, którego założenia odrzuca językoznawstwo pragmatyczne (poststrukturalne).

Nie należy jednak zapominać o sugestii Adama Weinsberga na temat możliwego rozumienia strukturalizmu nie jako zespołu doktryn językoznawczych, które dają się ulokować w historii studiów nad językiem (dominujących w latach 1930-1960), lecz jako zasady metodologicznej:

Zasada ta głosi, że badacz powinien opisywany przez siebie zespół zjawisk traktować świadomie i otwarcie jako system. A to z kolei wymaga [...] uznania istotności [...] pewnych cech tych zjawisk, a nieistotności innych, i to z jakiegoś punktu widzenia, wspólnego dla całego badanego zespołu" 36 .

Gdy patrzy się z zaproponowanej tu perspektywy, zrozumiałe staje się też stanowisko Adama Pawłowskiego o systemowym charakterze wiedzy w ludzkim umyśle. Wówczas faktycznie jednym ze sposobów pozwalających na odkrycie schematów poznawczych jednostki okazuje się badanie ich zewnętrznych manifestacji ${ }^{37}$.

Dodajmy, iż owo badanie może odbywać się w aspekcie zarówno synchronicznym, jak i diachronicznym. Implikacje wypływające $\mathrm{z}$ takiego założenia uzmysławiają — w ujęciu Jarosława Łachnika — istotę modelu słowotwórczego jako „historii” derywacyjnej wyrazu pochodnego ${ }^{38}$. Co więcej, dzięki odwołaniu do koncepcji słowotwórstwa niebinarnego (stanowiącego przecież podstawę opisu gniazdowego) możliwe stanie się wyjaśnienie, w jaki sposób odbiorca popkultury potrafi odnaleźć związki pomiędzy tymi elementami supersystemu rozrywkowego, które nie są jedynie prostym rozwinięciem pierwotnego pomysłu. Reprezentatywne pod tym względem pozostaje zwłaszcza zjawisko cross-overów, coraz częściej wykorzystywane przez autorów supersystemów rozrywkowych do ich rozbudowy. Polega ono na tworzeniu ,nadsystemu” łączącego osobne dotychczas supersystemy rozrywkowe w jedną całość; przykładem służą Superbohaterowie Marvela: Tajne Wojny (Marvel Super Heroes Secret Wars, 1984-1985, pol. 2013) Jima Shootera, Mike'a Zecka i Boba Laytona. Opowieść o dysponującej nadnaturalnymi siłami istocie zwanej Beyonderem stała się w tym wypadku pretekstem

${ }^{36}$ A. Weinsberg, Językoznawstwo ogólne, Warszawa 1983, s. 20.

37 Zob. A. Pawłowski, Struktura ilościowa pól leksykalnych a procesy poznawcze człowie$k a$, „Studia Semiotyczne” 27, 2010, s. 73, http://studiasemiotyczne.pts.edu.pl/tomy/XXVII_teksty/ XXVII_06.pdf (dostęp: 24.11.2017).

${ }^{38}$ Zob. J. Łachnik, Podstawy metodologiczne gniazdowego opisu złożeń i ich roli w systemie stowotwórczym polszczyzny, „LingVaria” 2009, nr 1, s. 112. 
do ukazania walk dotychczasowych antagonistów, znanych odbiorcy z różnych komiksowych serii publikowanych przez Marvel Comics. Na kartach wspomnianej opowieści pojawiają się między innymi Spiderman, Hulk, Iron Man, Thor, Kapitan Ameryka, Wolverine.

Crossover (a do pewnego stopnia również charakterystyczny dla „supersystemów rozrywkowych", spin-off) można — ze wspomnianej uprzednio perspektywy językoznawstwa niebinarnego - traktować jako zjawisko analogiczne do wspominanej przez Łachnika „historii” derywacji, jako świadectwo tworzenia nowych sensów kulturowych przez dodawanie do ,archetekstu” założycielskiego dla danego supersystemu rozrywkowego kolejnych tekstów kultury modyfikujących jego pierwotne znaczenie. W obrębie danego uniwersum historie opowiadane $\mathrm{z}$ innej niż pierwotna perspektywy (a w tym tkwi istota spin-offu) nie tylko wzbogacają świat przedstawiony, lecz także z różnorakich kierunków naświetlają zdarzenia, które nierzadko okazują się kluczowe dla całości supersystemu; pozwalają też na kreowanie alternatywnych linii rozwoju fabuły. Do pewnego stopnia umożliwiają zatem realizację koncepcji ,światów możliwych”, rozumianych — w myśl koncepcji „małych światów” Jaakka Hintikki — jako „względnie krótkie ciągi lokalnych zdarzeń w zaułku świata głównego” („A relatively short course of local events in some nook or corner of the actual world") ${ }^{39}$. Odwołanie do tej koncepcji dostarcza podstaw, by traktować jako całość jednego „supersystemu rozrywkowego" serial i powieści współtworzące projekt ${ }^{40}$ „Walking Dead”, mimo iż w dylogii Roberta Kirkmana i Jaya Bonansingi Upadek Gubernatora (2013-2014, pol. 2014) ciąg zdarzeń doprowadzający do śmierci tytułowej postaci ukazany został odmiennie niż w serialu (odcinek 8 sezonu 4: Too Far Gone, reż. Ernest Dickerson, USA 2013); można też rozwiązanie to odczytywać w kontekście wspomnianej uprzednio Hjelmslevowskiej koncepcji relacji właściwej znakom językowym, dla której badacz rezerwuje termin „tworzenie przez analogię”.

Kluczem interpretacyjnym pozwalającym na spojrzenie na oba przywołane tu fenomeny z kręgu supersystemów jako na analogiczne - ze względu na

39 J. Hintikka, Exploring Possible Worlds, [w:] Possible Worlds in Humanities, Arts and Sciences. Proceedings of Nobel Symposium 65, red. S. Allén, Berlin-New York 1989, s. 55.

40 Termin ,projekt”, biorąc pod uwagę jego zawartość semantyczną, zakłada intencjonalność tworzenia takiej opowieści, która ma potencjał rozwijania się w różnych mediach. Podobnie dzieje się z ,supersystemem rozrywkowym”, w którego przypadku twórcy implicite przyjmują, że będzie on dostępny dla użytkowników wielu platform medialnych (resp. mediów kultury), samemu kreując niejako „metaplatformę” w takim sensie, w jakim — zdaniem Alana Kaya i Adele Goldberg (Personal Dynamic Media, „Computer” 1977, nr 3) - komputer stanowi „metamedium”; piszą oni (ibidem, s. 41): „If such a machine were designed in a way that any owner could mold and channel its power to his own needs, then a new kind of medium would have been created: a metamedium, whose content would be a wide range of already-existing and not-yet-invented media". Współcześnie rolę tę przejęła sieć internetowa. Zob. M. Filiciak, Internet - społeczne metamedium, [w:] Media audiowizualne. Podręcznik akademicki, red. W. Godzic, współpr. A. Drzał-Sierocka, Warszawa 2010, s. 105, http://depot.ceon.pl/bitstream/handle/123456789/982/Internet\%20-\%20 spo\%C5\%82eczne\%20metamedium.pdf?sequence=1\&isAllowed=y (dostęp: 24.11.2017). 
mechanizmy regulujące ich funkcjonowanie w przestrzeni społecznej — wobec zjawisk opisywanych przez słowotwórstwo gniazdowe wydaje się uwaga Haliny Satkiewicz na temat roli schematu mającego człony o dookreślonym ustosunkowaniu i powtarzających się wykładnikach, w który zostają ,wpisane” kolejne szeregi słowotwórcze ${ }^{41}$. Choć bowiem intencjonalnie badaczka podejmuje kwestie z kręgu słowotwórstwa, mechanizm przez nią eksplikowany nie ogranicza się do zagadnień językoznawczych. Nieprzypadkowo przecież Lévi-Strauss właśnie w języku upatrując odzwierciedlenia przemian kulturowych, deklarował:

Język jest najdoskonalszym ze wszystkich przejawów porządku kulturowego, tworzących systemy na tej czy innej zasadzie. I jeśli chcemy zrozumieć, czym jest sztuka, religia, prawo, a może nawet i kuchnia lub zasady uprzejmości, należy je rozumieć jako kody utworzone przez artykulację znaków, według modelu lingwistycznego porozumiewania się ${ }^{42}$.

Co więcej, jeśli chcielibyśmy pozostać wierni założeniom słowotwórstwa gniazdowego, naszkicowany tu proces konwergencji supersystemów rozrywkowych w całość nadrzędną pozostaje tożsamy pod względem mechanizmów regulujących oba zjawiska. Potwierdzenie dotychczasowych supozycji o nieredukowalnym do sumy arytmetycznej znaczeniu ,supersystemów rozrywkowych” znajdujemy zatem w konstatacji Hanny Jadackiej na temat motywacji wzajemnej: „W strukturze hierarchicznej, jaką jest gniazdo, nie jest możliwe ani umieszczenie tego samego derywatu w różnych miejscach układu, ani lokowanie na tym samym poziomie dwóch rożnych struktur"43. Per analogiam do omawianego przez badaczkę mechanizmu cross-over nie może być rozpatrywany w strukturze danego supersystemu rozrywkowego jako zjawisko wielomotywowane bądź motywowane wzajemnie bez odniesienia do innego projektu (przeciwnie spin-off: w jego wypadku zdarzenia motywowane są wewnątrz danego supersystemu rozrywkowego).

$$
* * *
$$

Współcześnie nauka o języku (przede wszystkim lingwistyka kulturowa zakorzeniona w semantyce interpretacyjnej Donalda Davidsona oraz François Rastiera) traktuje przedmiot swych badań nie tyle jako narzędzie komunikacji spo-

${ }^{41}$ Zob. H. Satkiewicz, Produktywne typy słowotwórcze współczesnego języka ogólnopolskiego, Warszawa 1969, s. 194.

42 G. Charbonnier, Rozmowy z Claude Lévi-Straussem, przeł. J. Trznadel, Warszawa 1968, s. 142. Propozycję Levi-Straussa należy rozumieć jako rozwinięcie dylematów F. de Saussure'a, który — zastanawiając się nad granicami językoznawstwa — stawiał pytania (Kurs językoznawstwa ogólnego, przeł. K. Kasprzyk, wstęp, przypisy K. Polański, Warszawa 2002, s. 34): „Czy [...] należy wcielić językoznawstwo do socjologii? Jakie związki zachodzą między nim a psychologią społeczną? W gruncie rzeczy w języku wszystko jest psychologiczne [...], a ponieważ językoznawstwo dostarcza psychologii społecznej tak cennych danych, czy nie pokrywa się z nią całkowicie?”.

${ }^{43}$ H. Jadacka, Teoretycznostowotwórcze podstawy opisu, [w:] Zeszyt próbny słownika gniazd słowotwórczych współczesnego języka ogólnopolskiego, oprac. H. Jadacka, Warszawa 1988, s. 32. 
łecznej, ile — w myśl supozycji Janusza Anusiewicza — jako integralny element kultury. Ta zaś postrzegana jest jako system znaczeń symbolicznych ${ }^{44}$. Takim samym jednakże elementem kultury pozostają supersystemy rozrywkowe, których istotę stanowi transmedialny charakter opowieści. Z perspektywy semiotycznej tak samo jak system językowy są one znakiem.

Być może zatem sięgnięcie po instrumentarium opisu mechanizmów rządzących językiem - ze względu na jego swoisty charakter — pozwoli na adekwatniejszy (niż w przypadku stosowania metodologii spoza nauk humanistycznych) namysł nad istotą zjawisk kulturowych (tu: supersystemu rozrywkowego). Co więcej, przesunięcie akcentu uwagi z perspektywy ontologicznej (to jest poszukiwania odpowiedzi na pytanie, czym ,supersystem rozrywkowy” jest/nie jest) na epistemologiczną (to znaczy na próbę zrozumienia, w jaki ów sposób system funkcjonuje w przestrzeni społecznej, czyli jak ,jest używany”) wydaje się zgodne z zauważanym przez Macieja Grochowskiego przejściem od językowego strukturalizmu do paradygmatu poststrukturalistycznego ${ }^{45}$.

Nie inaczej przecież rozpatruje leksemy przywołany uprzednio Rastier, nie poddając analizie ich znaczeń, lecz skupiając się na opisie sensu powstającego w obrębie całego tekstu z uwzględnieniem kontekstu (ten zaś obejmuje, oprócz tekstu, jeszcze intertekst oraz czynnik gatunkowy); sens rodzi się wówczas z pracy interpretacyjnej traktowanej jako efekt interakcji między tekstem a jego czytelni$\mathrm{kiem}^{46}$. Podobnie sens supersystemu rozrywkowego powstaje w trakcie odczytywania powiązań jego poszczególnych elementów i relacji między tymi elementami. Konfrontując się z różnymi (pod względem medium) składowymi danego projektu artystycznego, konsument popkultury będzie poszukiwał ,powinowactw z wyboru" - tego, co dany supersystem rozrywkowy współkreuje, niezależnie od medium aktualizującego dane treści. Przykładowo, w wypadku jednego z najbardziej rozpoznawalnych i rozbudowanych supersystemów rozrywkowych, jakim są „Gwiezdne Wojny”, będą to nie tylko filmy i literatura, lecz także komiksy, klocki Lego, gadżety kolekcjonerskie, sesje cosplay, gry, twórczość amatorska (tak zwane fan arts), tapety i „motywy” komputerowe, a nawet tematyczne parki rozrywki. Dzieje się tak dlatego, że — jak podkreślają Jay David Bolter i Richard Grusin — poszczególne media supersystemu rozrywkowego remediują, kreując metasystem wzajemnie na siebie oddziałujących mediów (resp. elementów da-

${ }^{44}$ Zob. J. Anusiewicz, Lingwistyka kulturowa. Zarys problematyki, Wrocław 1994, s. 3, 12, 66.

45 Zob. M. Grochowski, Strukturalizm i poststrukturalizm w polskim językoznawstwie synchronicznym (refleksje metodologiczne), „Biuletyn Polskiego Towarzystwa Językoznawczego" 2011, z. 67, s. 21-25.

46 Zob. K. Wołowska, Czy analiza składnikowa jest metoda przestarzała? Rozwój badań nad struktura semantyczna jednostek leksykalnych we wspótczesnym językoznawstwie francuskim, „Linguistica Copernicana” 2010, nr 1, s. 145, http://www.linguistica.umk.pl/teksty/03_wolowska. pdf (dostęp: 24.11.2017); H. Grzmil-Tylutki, Francuska lingwistyczna teoria dyskursu. Historia, tendencje, perspektywy, Kraków 2010, s. 29. 
nego supersystemu rozrywkowego), w taki zatem sposób media te powinny być rozważane $w$ perspektywie teoretycznej ${ }^{47}$.

Być może więc badający zjawiska z kręgu popkultury nie powinni ograniczać się w swych inspiracjach metodologicznych do teorii kulturoznawczych, lecz - niejako wbrew tendencjom do antropologizacji dyskursu humanistycznego - „powrócić do źródeł” i sięgnąć po metody językoznawcze pozwalające na dostrzeżenie alternatywy dla wspomnianych tendencji. Jednym z rozwiązań jest — w myśl supozycji Antoine'a Compagnona — zwrot w stronę filologicznej natury tekstu kultury; badacz explicite rozważał status literatury, można jednak jego wnioski zastosować również do innych zjawisk kulturowych. Compagnon pisał: „Formalizm, zbudowany na językoznawstwie i odświeżony przez strukturalizm, uwalnia badanie literatury od rozważań niedotyczących słownej natury tekstu"48. W ten sposób na gruncie językoznawstwa i współczesnej filozofii języka obiektem studiów staje się - przywołajmy uwagę Piotra Feligi, komentującego myśl Hansa-Georga Gadamera - zasób środków wykorzystywanych przez ludzki umysł w celu realizacji kompetencji językowej ${ }^{49}$.

Jest to ograniczenie metodologiczne jedynie pozorne; przypomnijmy, iż metody stosowane przez językoznawstwo nie tylko legły u podstaw wiedzy o języku, lecz także w przemożny sposób wpłynęły na teorię literatury, a pośrednio i na metody badania kultury — jak choćby w wypadku strukturalizmu bądź etnolingwistyki ${ }^{50}$. Z kolei Katarzyna Grudzińska, pisząc o kulturowej teorii języka, odwołuje się do koncepcji językowego obrazu świata i jego lingwistycznych wykładników

47 J.D. Bolter, R. Grusin, Remediation: Understanding of New Media, Cambridge [Mass.] 1999, s. 337-343, 345-348.

${ }^{48}$ A. Compagnon, Demon teorii. Literatura a zdrowy rozsądek, przeł. T. Stróżyński, Gdańsk 2010, s. 32. O możliwościach zastosowania osiągnięć szkoły formalizmu rosyjskiego w badaniach nad zjawiskami z pogranicza literaturoznawstwa i językoznawstwa zob. I. Pilszczikow, Dziedzictwo rosyjskiej szkoły formalnej. OPOJAZ i Moskiewskie Koło Lingwistyczne a wspótczesna filologia, przeł. A. Berkieta, „Przestrzenie Teorii” 2011, nr 16, http://repozytorium.amu.edu.pl/bitstream/10593/2099/1/279-298.pdf (dostęp: 24.11.2017).

49 Zob. P. Feliga, Czas i ortodoksja. Hermeneutyka teologii w świetle „Prawdy i metody” Hansa-Georga Gadamera, Torun 2014, s. 262.

${ }^{50} \mathrm{O}$ ile wpływ strukturalistycznie zorientowanych szkół językoznawczych (m.in. szkoły genewskiej, szkoły kopenhaskiej, Praskiego Koła Lingwistyki) został doskonale rozpoznany i opisany, o tyle kwestia oddziaływania etnolingwistyki na badania kultury wciąż pozostaje relatywnym novum. Znaczący przy tym jest, eksplikowany przez Jerzego Bartmińskiego (Czym zajmuje się etnolingwistyka, „Akcent” 1986, nr 4), proces rozszerzania obszaru refleksji lingwistów zainteresowanych folklorem na zjawiska pozajęzykowe. Do pewnego stopnia analogiczne mechanizmy możemy zauważyć w badaniach socjolingwistycznych (przede wszystkim socjolektu), w których głównym źródłem pozostaje literatura. Zob. B. Walczak, Literatura piękna jako źródto do badań z zakresu socjolingwistyki historycznej, „Annales Universitatis Paedagogicae Cracoviensis. Studia Linguistica” 8, 2013.

Literatura i Kultura Popularna 24, 2018

(C) for this edition by CNS 
w leksyce; dodaje przy tym: „Język to nie tylko najważniejszy przekaźnik treści kulturowych, ale także integralny składnik kultury"51.

W przywołanych tu słowach pobrzmiewa konstatacja Foucaulta, który kreśląc obszar zainteresowań humanistyki — deklarował:

Przedmiotem nauk humanistycznych nie jest $[\ldots]$ język [...], lecz byt, z wnętrza otaczającej go mowy przedstawiający sobie w mówieniu sens wypowiadanych słów czy zdań i w końcu uznający siebie za reprezentację samego języka ${ }^{52}$.

Uwaga badacza dotycząca językowej natury zjawisk rzeczywistości społecznej wydaje się tym istotniejsza, że - co akcentuje Ryszard Nycz na marginesie refleksji nad przesłankami sprzyjającymi antropologizowaniu studiów literackich - wszędzie tam, gdzie uczony zadaje pytania o istotę i znaczenie obserwowanych zjawisk, odnajduje się w obszarze rozumienia językowego ${ }^{53}$. Nieprzypadkowo Stefan Żółkiewski, omawiając propozycję metodologiczną Ferdinanda de Saussure'a, zastrzegat:

Nie chodzi [...] o zastąpienie metod badawczych różnych dyscyplin przez metody językoznawcze, co byłoby nonsensem, ale o wykorzystanie technik analiz systemowych jako pomocniczego postępowania badawczego w różnych dyscyplinach humanistycznych ${ }^{54}$.

Być może zatem spojrzenie na fakty kulturowe, jakimi są supersystemy rozrywkowe, przez pryzmat ustaleń lingwistyki pozwoli dostrzec nie tylko ich „słowną" (w rozumieniu Compagnona) naturę, lecz także ich uwikłanie w język traktowany jako narzędzie rozumienia i opisu rzeczywistości ${ }^{55}$.

${ }^{51}$ K. Grudzińska, Rozwój kulturowej teorii języka - od filozofii i etnolingwistyki do dydaktyki, „Episteme” 1, 2014, s. 35.

52 M. Foucault, Stowa i rzeczy. Archeologia nauk humanistycznych, przeł. T. Komendant, Gdańsk 2006, s. 317. Zob. też R. Tokarski, Stownictwo jako interpretacja świata, [w:] Współczesny język polski, red. J. Bartmiński, Lublin 2012 (tu bogata literatura przedmiotu).

53 Zob. R. Nycz, Antropologia literatury - kulturowa teoria literatury - poetyka doświadczenia, „Teksty Drugie” 2007, nr 6, s. 40-41. Oczywiście — jak zauważa Nycz (ibidem, s. 40) - ustalenia językoznawcze nie mogą być postrzegane jako remedium na pokusy zwrócenia się ku dziedzinom pozajęzykowym (obrazowi, emocjom, kategorii cielesności) w interpretacji tekstu kultury. O pułapkach czyhających na badaczy obdarzających metody językoznawcze nadmiernym zaufaniem pisze (na przykładzie semantyki strukturalnej) J. Linde-Usiekniewicz (op. cit., s. 171).

54 S. Żółkiewski, Przedmowa, [w:] Semiotyka kultury, wyb., oprac. E. Janus, M.R. Mayenowa, Warszawa 1977, s. 15.

${ }^{55}$ Co więcej, można by — parafrazując supozycję Ireny Hübner (Semiotyka a literatura i literaturoznawstwo, „Acta Universitatis Lodziendzis. Folia Litteraria Polonica” 2005, t. 7, s. 33, http:// dspace.uni.lodz.pl:8080/xmlui/bitstream/handle/11089/9015/15-35.pdf (dostęp: 24.11.2017) — zauważyć, że interpretacja tekstu kultury (jakim jest także „supersystem rozrywkowy”) wymaga od konsumenta popkultury aktywności analogicznej do tej niezbędnej do zrozumienia komunikatu językowego. 


\section{Aneks}

\section{Strategie wykorzystywania relacji charakterystycznych dla znaków językowych w supersystemach rozrywkowych (na przykładzie supersystemu rozrywkowego ,Metro 2033")}

Wywodząca się z myśli strukturalistycznej koncepcja Louisa Hjelmsleva z uwagi na jej pokrewieństwo z semiotyką - wydaje się najodpowiedniejszym narzędziem językoznawczym umożliwiającym badanie złożonych struktur, jakimi są supersystemy rozrywkowe. Punktem odniesienia uczyniono — zgodnie z zasygnalizowanym założeniem — relacje, które Hjelmslev uznał za swoiste dla znaków językowych. Współtworzące supersystem rozrywkowy teksty kultury potraktowano jako zjawiska analogiczne do owych znaków; stało się to możliwe, ponieważ założenia strukturalizmu pozwalają na wyeksponowanie poszczególnych elementów danego supersystemu rozrywkowego i zachodzących między nimi relacji. Zarazem — dzięki przeniesieniu akcentu uwagi ze znaku właśnie na relacje, w które wchodzi on $\mathrm{z}$ innymi znakami w ramach danej struktury — zrozumiałe stają się obserwowalne zmiany diachroniczne, które nie są obojętne dla całości ${ }^{56}$. Nieprzypadkowo Hjelmslev, pisząc o funkcjonowaniu znaków językowych, podkreślał ich społeczny charakter: to bowiem użytkownicy — poprzez swoją aktywność językową — decydują o trwaniu (oraz zaniku) danego znaku ${ }^{57}$.

Per analogiam: w odniesieniu do „supersystemu rozrywkowego" możliwe staje się dostrzeżenie nie tylko charakteru związków między poszczególnymi tekstami wchodzącymi w skład systemu na różnym poziomie semantycznym (adaptacja do innego medium, crossover, prequel, sequel, spin-off), ale i prześledzenie zmian powodowanych przez rozbudowę pierwotnej koncepcji w rożnych mediach.

W skład popularnego systemu „Metro 2033” wchodzą teksty kultury aktualizowane właśnie za pomocą rozmaitych środków masowego przekazu — zarówno literatura autorstwa profesjonalistów i amatorów (fan fiction), jak i dzieła o charakterze audiowizualnym: gry komputerowe i projektowane na urządzenia mobilne, a także teledysk promujący utwór literacki oraz komiks i krótkometrażowy film ${ }^{58}$. Dodatkowo dla miłośników supersystemu dostępne są gadżety

${ }^{56}$ Zob. J.H. Greenberg, Rola typologii w rozwoju nauki o języku, przeł. A. Weinsberg, [w:] Językoznawstwo strukturalne. Wybór tekstów, red. H. Kurkowska, A. Weinsberg, Warszawa 1979, s. 239.

57 Zob. L. Hjelmslev, Jazyk..., s. 43.

58 Przywoływany tu film — zrealizowany przez niezależną wytwórnię Red Horizont Studio — dostępny jest w sieci internetowej. Zob. Metro 2033: Last Hope - Live Action, reż. P. Kwidzyn- 
o charakterze software'owym (tapety komputerowe), kalendarze i drobne akcesoria (kubki, koszulki z nadrukiem nawiązującym do motywów projektu „Metro 2033 ", latarki) ${ }^{59}$. Jako osobne zagadnienie należy rozpatrywać stylizowane na estetykę omawianego supersystemu rozrywkowego tak zwane nakładki (mods) na różne gry komputerowe; przykładem służy Grand Theft Auto Metro 2033 oraz Minecraft Metro $2033^{60}$. Zwłaszcza ostatnia z przywołanych tu nakładek, oferująca nieliniowy tryb rozgrywki, zdaje się podkreślać chaos, którym zostaje naznaczone życie bohaterów w świecie przedstawionym supersystemu rozrywkowego „Metro 2033”; zarazem kubistyczna estetyka podkreśla dystans do przedstawianych zdarzeń.

Badając relacje między poszczególnymi tekstami kultury w ramach nadrzędnego świata przedstawionego przez pryzmat relacji właściwych systemom językowym możemy wyróżnić:

- przemieszczanie,

- skracanie,

- tworzenie przez analogię.

Kolejno je omówię.

\section{Przemieszczanie}

Strategia ta realizowana jest głównie przez pisarzy spoza krajów byłego ZSRR; mamy tu na myśli następujące utwory: Korzenie niebios (Le Radici del cielo, 2011, pol. 2013) Tullio Avoleda; Dzielnice obiecana (2014) Pawła Majki oraz Otchtań (2015) i Wieżę (2016) Roberta J. Szmidta. Należy też uwzględnić trzy tomy opowiadań twórców nieprofesjonalnych: W blasku ognia. Wybór najlepszych opowiadań polskich fanów Uniwersum Metro 2033 (2014); Szepty zgładzonych. Opowiadania polskich fanów uniwersum Metro 2033 (2015) oraz Echo zgasłego świata. Opowiadania polskich fanów uniwersum Metro $2033(2016)^{61}$.

ski et al., Polska 2014, http://www.youtube.com/watch?v=8D-vH4cPXtg (dostęp: 2.03.2016). Zob. też Krakus [właśc. ?], Podziemia Nowej Huty, Forgotten Places, http://www.forgotten.pl/miejsce. php?id=684 (dostęp: 8.06.2016).

59 Wymienione tu gadżety nie rozbudowują supersystemu „Metro 2033” w takim sensie, jak współtworzące go teksty kultury. Dostępność tych przedmiotów stanowi jednak czynnik podkreślający ekonomiczny wymiar zjawiska, uzmysławiając, iż kultura fanów to również silna presja rynkowa, oddziałująca na producentów popkultury. Rozważany z tej perspektywy, supersystem staje się fenomenem marketingowym, do którego opisu możliwe jest zastosowanie instrumentarium badawczego właściwego dla ekonomii.

${ }^{60}$ Nakładki dostępne są — odpowiednio - na stronach: ModDB, http://www.moddb.com/ mods/grand-theft-metro-2033 (dostęp: 13.06.2016), oraz Planet Minecraft, http://www.planetminecraft.com/texture_pack/metro-2033-1152659 (dostęp: 13.06.2016).

61 Wykorzystanie w podtytule antologii terminu ,uniwersum” wprowadza niejaki chaos terminologiczny. Ukierunkowuje bowiem uwagę czytelnika na świat przedstawiony, który w koncepcji Kinder jest mniej istotnym wyróżnikiem supersystemu rozrywkowego niż konstytutywny dla niego bohater (kategoria świata wywodzi się z kolei z koncepcji opowiadania transmedialnego 
Przeniesienie i dostosowanie (bo tym $\mathrm{w}$ istocie jest przemieszczanie $\mathrm{w}$ ramach supersystemu) tych powieści do lokalnych realiów kulturowo-społecznych wymusiła konieczność znalezienia analogii dla zachowań społecznych, które gdyby nie zostały zmodyfikowane - byłyby niejasne dla czytelników nieznających oryginalnego kontekstu społeczno-kulturowego. Szczególnym przykładem takiego przemieszczenia jest sytuowanie akcji opowieści poza korytarzami kolei podziemnej: w powieści Avoledy analogiczną funkcję pełnią katakumby i naturalne jaskinie pod Watykanem, a w Dzielnicy obiecanej Majki — schrony i kryjówki zaprojektowane przez budowniczych Nowej Huty ${ }^{62}$.

\section{Skracanie}

Jest to zabieg właściwy tekstom kultury nawiązującym do pierwowzoru literackiego i pozostającym $\mathrm{z}$ nim $\mathrm{w}$ relacji transmedialnej; reprezentatywna pod tym względem okazuje się zwłaszcza opowieść graficzna Dmitrija Głuchowskiego, Landry'ego Q. Walkera, Paula Azaceta i Matthew Wilsona Metro: Last Light: The Gospel According to Artyom (2013). Zgodnie z tytułem nawiązuje ona tyleż do gry Metro: Last Light (prod. 4A Games, wyd. Deep Silver, Ukraina 2013), ile do powieści Metro 2033 (2005, pol. 2010). Co więcej, komiks ten należy odczytywać również w kontekście dołączonego do niej quasi-apokryfu Ewangelia według Artema, stanowiącego propozycję alternatywnego zakończenia.

Nie inaczej wykorzystali potencjał artystyczny tkwiący w relacji transmedialnej twórcy teledysku promującego powieść Szmidta Wieża (2016), towarzyszącego piosence Pociag do piekła bram (2016) zespołu Lux Perpetua ${ }^{63}$. W skon-

H. Jenkinsa [Kultura konwergencji. Zderzenie starych i nowych mediów, przeł. M. Bernatowicz, M. Filiciak, Warszawa 2007, s. 35]). Pewnym — jakkolwiek połowicznym i przez to niesatysfakcjonującym badawczo - rozwiązaniem problemu byłoby nadanie światu przedstawionemu w projekcie artystycznym „Metro 2033” statusu bohatera. Musielibyśmy jednak w takim przypadku zgodzić się na tematyzację kategorii świata przedstawionego, który przestanie wtedy być jedynie scenerią akcji fabularnej. Zaproponowane tu założenie ma wszakże poważne konsekwencje interpretacyjne. Wskazuje na nie K. Dominas (Tekst i jego dodatki, dodatki i tekst —od supersystemu rozrywkowego do uniwersum kulturowego, „Forum Poetyki” 2016, nr 3, s. 32, http://fp.amu.edu.pl/tekst-i-jego-dodatki-dodatki-i-tekst-od-supersytetmu-rozrywkowego-do-uniwersum-kulturowego (dostęp: 20.12.2016), traktując uniwersum jako limes funkcjonowania zarówno supersystemu rozrywkowego, jak i opowieści transmedialnej.

${ }^{62}$ Dokumentacja jednego ze schronów (pod kinem nowohuckim Światowid na osiedlu Centrum E) dostępna jest w postaci nagrania filmowego w serwisie YouTube: J. Biernacki, Nowa Huta, schron pod kinem Światowid, http://www.youtube.com/watch?v=m73uilkM18g (dostęp: 8.06.2016); zob. też R. Radłowska, Schrony i miejsca ukrycia, czyli nowohuckie osobliwości, „Gazeta Wyborcza” 25.11.2014, http://krakow.wyborcza.pl/krakow/1,44425,17022114,Schrony_i_miejsca_ukrycia_czyli_nowohuckie_osobliwosci.html?disableRedirects=true (dostęp: 8.06.2016).

63 Teledysk dostępny jest w serwisie YouTube: Insignis Media, Uniwersum Metro 2033: Wie$\dot{z} a$ - oficjalny teledysk zespót Lux Perpetua, http://www.youtube.com/watch?v=j21LjE80jFQ (dostęp: 11.06.2016), opatrzony podpisem „Oficjalny teledysk promujący powieść Uniwersum 2033: Wieża". 
densowany sposób ukazali fabułę powieści, posiłkując się estetyką właściwą nowoczesnemu wideoklipowi ${ }^{64}$. Koncentrując się na wątkach zogniskowanych wokół protagonistki, dokonali swoistego streszczenia powieści, eksponującego sceny najatrakcyjniejsze fabularnie. Nadając alternatywne sensy temu, co zaprezentowała powieść, nie zrezygnowali zarazem z linearności fabuły, kreśląc ją w taki sposób, aby sceny ukazujące muzyków stały się integralne $\mathrm{z}$ opowiadaną przez nich historią. Dzięki takiemu rozwiązaniu twórcy Pociagu do piekła bram nawiązali dialog estetyczny z teledyskiem promującym grę komputerową Metro 2033 (prod. 4A Games, wyd. THQ, Ukraina 2010), w którym wykorzystano utwór Mein Teil (2004) zespołu Rammstein ${ }^{65}$ (powinowactwo podkreślone jest również poprzez sięgnięcie przez oba zespoły do estetyki muzyki z pogranicza hard rocka i heavy metalu ${ }^{66}$ ). Przeciwnie jednak niż w wypadku utworu Lux Perpetui, utwór Rammsteinu w warstwie tekstowej nie stanowi parafrazy gry należącej do supersystemu rozrywkowego „Metro 2033”67. Co więcej, fabułę teledysku można uznać za wprowadzenie (prequel) do gry, podczas gdy teledysk towarzyszący Pociagowi do piekła bram odzwierciedla fabułę utworu, który promuje (co stanowi pochodną funkcji marketingowej, jaką pełni teledysk).

\section{Tworzenie przez analogię}

Szczególnie wyrazistym przykładem ,powinowactw z wyboru” są związki łączące powieść Głuchowskiego Metro 2035 (2015, pol. 2015) z chronologicznie wcześniejszymi dziełami jego autorstwa. Korzystając z realiów świata przedstawionego wymyślonego na potrzeby cyklu (a pośrednio również rzeczywistości „Metro 2033”), pisarz zaproponował utwór, który — rozważany jako domknięcie opowieści o przygodach głównego bohatera cyklu (a tak właśnie promowane jest

${ }^{64}$ Zob. M. Lisowska-Magdziarz, Bunt na sprzedaż. Przemyst muzyczny - reklama — semiotyka, Kraków 2000, s. 84.

65 Zob. https://www.youtube.com/watch?v=PBvwcH4XX6U (dostęp: 11.07.2017).

${ }^{66}$ Nie miejsce tu, by rozważać potencjalne zapożyczenia zespołu Lux Perpetua z twórczości Rammsteinu i inspiracje nim; być może jednak świadomość, iż niemieccy muzycy wpisują się w nurt Neue Deutsche Hätre, wyjaśnia, dlaczego - mimo postapokaliptycznej scenerii świata przedstawionego projektu „Metro 2033” i mimo tego, że perypetie bohaterów rozgrywają się na ruinach wielkomiejskich aglomeracji — oba zespoły zrezygnowały z sięgnięcia do estetyki muzyki postindustrialnej, oferowanej przez nurt techno. Estetyka ta bowiem w mniejszym stopniu niż obrane rozwiązanie podkreślałaby w odpowiednim stopniu ideologicznego aspektu systemu „Metro 2033”, podporządkowanego filozofii inspirowanej międzywojennymi wizjami kresu cywilizacji. Szerzej na temat specyfiki Neue Deutsche Härte oraz związków tego zjawiska muzycznego z muzyką techno zob. S. Lindke, Der Tabubruch von heute ist der Mainstream von morgen - Die „Neue Deutsche Härte” als ästhetisches Spiegelbild der wiedererstarkten Nation, [w:] Ästhetische Mobilmachung. Dark Wave, Neofolk und Industrial im Spannungsfeld rechter Ideologien, red. A. Speit, Hamburg-Münster 2002; Y. Kegan, Neue Deutsche Härte, [hasło w:] Subgenres of the Beast. A Heavy Metal Guide, Lulu.com 2015, s. 1, s. 217-218.

${ }^{67}$ Zob. Rammstein, Mein Teil, [na płycie:] Reise, Reise, Motor Music 2004, utwór 2. 
Metro $2035^{68}$ ) - wprowadza modyfikacje do tego świata ${ }^{69}$. Co więcej, czyni to nie tylko w relacji do powieści, lecz także do całości supersystemu rozrywkowego „Metra 2033”, toteż owo dzieło można czytać bez znajomości poprzednich perypetii postaci ${ }^{70}$. Dagmara Trembicka-Brzozowska stwierdza wprost: „To dobra powieść, tak samodzielnie, jak i w trylogii »Metra«"71. Zacytowana uwaga w kontekście funkcjonowania powieści Głuchowskiego w ramach projektu „Metro 2033" - jedynie pozornie jest przejawem właściwego kulturze fanów dążenia do osadzenia tekstu w siatce wzajemnych zależności. W istocie bowiem podnosi istotną kwestię granic, poza którymi tekst kultury „usamodzielnia się”, przekraczając ramy danego supersystemu rozrywkowego. Toteż odpowiedź na pytanie o związki powieści Głuchowskiego Metro 2035 z supersystemem rozrywkowym „Metro 2033” pozwala wyznaczyć limes strategii tworzenia przez analogię ${ }^{72}$.

Osobnym zagadnieniem łączącym się z wykorzystaniem tej strategii pozostaje sytuacja, w której mamy do czynienia z dwoma deklaratywnie różnymi

68 Zob. D. Glukhowsky, Metro 2035 [reklama], Insignis.pl, http://www.insignis.pl/ksiazki/metro-2035 (dostęp: 9.06.2016); Metro 2035 [reklama], Metro2033.pl, http://metro2033.pl/metro2035/ ksiazka (dostęp: 9.06.2016); Premiera „,Metro 2035” Dmitrija Glukhovskyego!, CreatioFantastica. com, http://creatiofantastica.com/2015/10/27/premiera-metro-2035-dmitrija-glukhovskyego (dostęp: 9.06.2016).

${ }^{69}$ Nie jest to jednostkowy przykład tworzenia przez analogię w „supersystemach rozrywkowych". Podobna strukturalnie zależność łączy serię gier Fallout (prod. Black Isle Studios, wyd. Interplay Entertainment, USA 1997-) z grą Fallout Tactics: Brotherhood of Steel (prod. Micro Forté, wyd. Interplay Entertainment, Australia 2001). Zarazem istnieje gra Fallout: Brotherhood of Steel (prod. i wyd. Interplay Entertainment, USA 2004). Na temat relacji pomiędzy kolejnymi odsłonami gry zob. Seria Fallout - seria gier, GryOnline.pl, http://www.gry-online.pl/gry-z-serii-i-podobne. asp?ID=22 (dostęp: 3.03.2016).

${ }^{70}$ Zob. LadyWerewolf [właśc. ?], Metro 2035 - Dmitry Glukhovsky (recenzja przedpremierowa), Kawerna.pl, http://www.kawerna.pl/recenzje/ksiazka/item/10829-metro-2035-dmitry-glukhovsky-recenzja-przedpremierowa.html (dostęp: 9.06.2016); A. Mazurkiewicz, Pozycja osobna [rec. D. Głuchowski, Metro 2035], „Creatio Fantastica” 2015, nr 4, http://creatiofantastica.files. wordpress.com/2015/12/rec-adam-mazurkiewicz-pozycja-osobna.pdf (dostęp: 9.06.2016).

71 D. Trembicka-Brzozowska, I bez wrogów sobie radzimy [rec. D. Głuchowski, Metro 2035], Gildia.pl, http://www.literatura.gildia.pl/tworcy/dmitry-glukhovsky/metro-2035/recenzja (dostęp: 9.06.2016). O tym że przywołana tu opinia nie jest powszechnie podzielana, świadczy wypowiedź jednego z internautów na forum miłośników „supersystemu rozrywkowego” „Metro 2033”, GhostWriter [właśc. ?], post z 27.11.2015 w wątku: Metro 2035 — opinie!, http://metro2033.pl/phpbb/ viewtopic.php?f=54\&t=20956\&start=25 (dostęp: 9.06.2016): „nie wiem, skąd te dziwne zapowiedzi, że Metro 2035 jest powieścią niezależną od reszty trylogii. Czytając tylko ostatnią część, zrozumiemy zaledwie jej połowę; przecież nawiązań do wcześniejszych zdarzeń jest sporo. A jak zrozumieć postacie, na przykład taką Saszę czy nawet Artema, studiując jedynie ich losy na podstawie tylko Metra 2035?".

$72 \mathrm{O}$ tym, do jakiego stopnia istotna jest kwestia dookreślenia ram tekstu artystycznego (w tym wypadku supersystemu rozrywkowego), przekonuje lektura szkicu B. Uspienskiego (Strukturalna wspólnota różnych rodzajów sztuki (na przykładzie malarstwa i literatury), przeł. Z. Zaron, [w:] Semiotyka kultury, wyb., oprac. E. Janus, M.R. Mayenowa, Warszawa 1977, s. 189-190), który wyznacza im możliwość doprecyzowania episteme świata przedstawionego. 
supersystemami rozrywkowymi mającymi jednak tożsamy fabularny punkt wyjścia. Odrębność uniwersów „Metro 2033” i „Postapo” (scen. Daniel Gizicki, rys. Krzysztof Małecki) wyznaczają opracowanie edytorskie oraz logotyp serii, zatem znaki „zewnętrzne” wobec świata przedstawionego. Odczytywane wszakże z perspektywy koncepcji ,paratekstów” Gerarda Genette'a ukierunkowują one interpretację każdego z „,supersystemów rozrywkowych" na możliwe „powinowactwa z wyboru" "73. Oba supersystemy różni jednak też medium: twórcy „Metra 2033” sięgają (o czym wspomniano) po rozmaite tworzywa, „Postapo” zaś realizuje się dotychczas tylko w komiksie ${ }^{74}$.

Mielibyśmy tu zatem do czynienia ze szczególnym przypadkiem analogicznego pomysłu fabularnego dyskontującego artystyczny (ale i rynkowy) sukces chronologicznie wcześniejszego supersystemu rozrywkowego przez te powstałe później i dopiero rozwijające się. Co więcej, cykl komiksowy Gizickiego i Małeckiego można odczytywać przez pryzmat innego supersystemu: „Kompleksu 7215 ” zapoczątkowanego tak właśnie zatytułowaną ${ }^{75}$ powieścią Bartka Biedrzyckiego z 2014 roku. Jej punktem wyjścia, podobnie jak w zapoczątkowującej projekt „Metro 2033” powieści Głuchowskiego, jest obraz świata po dekadach od wybuchu wojny atomowej oraz losy grupy pierwszoplanowych bohaterów, których dzieje splatają się z sobą.

Poszukiwanie ,powinowactw z wyboru” pomiędzy projektami artystycznymi „Metro 2033”, „Postapo” oraz „Kompleks 7215” — ze względu na tożsame właściwości fabuły: jej schemat (ocalały $z$ atomowej pożogi protagonista szukający rodziny) oraz założenia (obraz świata po dziesięcioleciach od kataklizmu) — nakazuje zastanowić się, czy mamy w przypadku owych tekstów do czynienia z celowymi nawiązaniami pozwalającymi rozpatrywać poszczególne supersystemy rozrywkowe jako refleksy jednego „,nad-supersystemu”, czy też możliwe podobieństwa należy uznać za koincydencje wynikające właśnie z analogicznych założeń i z sięgania

73 Zob. G. Genette, Palimpsesty. Literatura drugiego stopnia, przeł. A. Milecki, T. Stróżyński, Gdańsk 2014.

${ }^{74}$ Dotychczas w cyklu ukazały się dwa tomy autorskie: D. Gizicki, K. Małecki, Postapo 1: Nienormalna normalność, [Warszawa] 2013; eidem, Postapo 2: Najpierw stychać grzmoty, Warszawa 2014; oraz: D. Gizicki et al., Postapo. Antologia, Warszawa 2015.

75 Gwoli ścisłości dodajmy, iż równolegle do nazwy „Kompleks 7215” funkcjonuje na rynku wydawniczym inna: „Opowieści z postapokaliptycznej aglomeracji”, której poszczególne tomy opatrzone zostały kolejnymi numerami. Zob. Opowieści z postapokaliptycznej aglomeracji. Tom 1. Kompleks 7215, http://www.empik.com/kompleks-7215-biedrzycki-bartek,p1099701829,ksiazka-p (dostęp: 9.06.2016); Opowieści z postapokaliptycznej aglomeracji. Tom 2. Stacja: Nowy Świat, http://www. empik.com/stacja-nowy-swiat-biedrzycki-bartek,p1107830521,ksiazka-p (dostęp: 9.06.2016); Upadła światynia, http://www.empik.com/upadla-swiatynia-weclawek-dominika,p1117699792,ksiazka-p (dostęp: 9.06.2016). W ramach projektu dotychczas ukazały się utwory: B. Biedrzycki, Kompleks 7215, il. R. Adler, Lublin 2014; B. Biedrzycki, Stacja Nowy Świat, il. R. Adler, Lublin 2015; D. Węcławek Upadła świątynia. Legendy zrujnowanego miasta, il. R. Szłapa, Lublin 2016. Poszczególne tomy zawierają, oprócz powieści, autorskie opowiadania, poszerzające świat przedstawiony, oraz mapy, wizualizujące (analogicznie zresztą jak w „supersystemie rozrywkowym” „Metro 2033”) przestrzeń akcji. 
po zunifikowane figury apokaliptyczne zakorzenione w imaginarium communis. Wątpliwości te nie ograniczają się zresztą jedynie do makrostruktur supersystemów, lecz sugerują, by podjąć namysł nad granicami inspiracji wykraczających nieraz poza koncepty fabularne współtwórców supersystemu rozrywkowego „Metro 2033" - jak dzieje się w wypadku powieści Majki Człowiek obiecany (2016); przywołany tu utwór pozostaje w zależności od powieści P.D. James [właśc. Phyllis Dorothy James] Ludzkie dzieci (The Children of Men, 1992, pol. 2006) oraz od jej ekranizacji opatrzonej tym samym tytułem (reż. Alfonso Cuarón, USA-Wielka Brytania 2006). Zbieżny w dziełach Majki i James jest pomysł fabularny związany z ochroną dziecka mającego stać się nadzieją ludzkości.

$$
* * *
$$

Rozważając implikacje metodologiczne badania mechanizmów regulujących funkcjonowanie ,supersystemów rozrywkowych” za pomocą instrumentarium właściwego językoznawstwu, łatwo można dojść do przekonania, że dzięki wykorzystaniu takich narzędzi przywrócone zostaje centralne miejsce tekstowi jako przedmiotowi analiz.

Przeorientowanie studiów kulturowych z uwarunkowań „zewnętrznych” na same teksty nie wyklucza przywoływania rozmaitych okoliczności, w których każdy z nich funkcjonuje (rynkowych, społecznych, medialnych, kulturowych; jest to konieczne, gdyż — w myśl tezy Jurija Łotmana i Borysa Uspienskiego dynamika kultury nierozerwalnie wiąże się z przemianami życia społecznego ${ }^{76}$ ). Powinny one być uwzględnione, lecz jedynie na prawach kontekstów. Nie bez znaczenia pozostaje spojrzenie na przedmiot badań z perspektywy semiotycznej, która - co przypomina Żółkiewski - nie będąc odrębną dyscypliną naukową, mimo wszystko dostarcza technik analitycznych pozwalających na uniwersalizację jej zastosowania ${ }^{77}$.

\section{Bibliografia}

\section{Źródła}

Avoledo T., Korzenie niebios, przeł. P. Drzymała, Insignis, Kraków 2013.

Biedrzycki B., Kompleks 7215, Fabryka Słów, Lublin 2014.

Biedrzycki B., Stacja Nowy Świat, Fabryka Słów, Lublin 2015.

${ }^{76}$ Zob. J. Łotman, B. Uspienski, O semiotycznym mechanizmie kultury, przeł. J. Faryno, [w:] Semiotyka kultury..., s. 163.

77 S. Żółkiewski, op. cit., s. 6-7. Na temat możliwych związków semiotyki z badaniami literatury zob. S. Morawski, Estetyka a semiotyka, „Pamiętnik Literacki” 1976, z. 3; I. Hübner, Semiotyka a literatura i literaturoznawstwo, „Acta Universitatis Lodziensis. Folia Litteraria Polonica” 7, 2005, http://dspace.uni.lodz.pl:8080/xmlui/bitstream/handle/11089/9015/15-35.pdf (dostęp: 24.11.2017). 
Echo zgastego świata. Opowiadania polskich fanów uniwersum Metro 2033, Insignis, Kraków 2016.

Gizicki D. et al., Postapo. Antologia, Wydawnictwo Dolna Półka, Warszawa 2015.

Gizicki D., Małecki K., Postapo 1: Nienormalna normalność, Wydawnictwo Dolna Półka, [b.m.w.] 2013.

Gizicki D., Małecki K., Postapo 2: Najpierw stychać grzmoty, Wydawnictwo Dolna Półka, [b.m.w.] 2014.

Głuchowski D., Metro 2035, Insignis, Kraków 2015.

James P.D. [właśc. Phyllis Dorothy James] Ludzkie dzieci, przeł. M. Głębicka-Frąc, Mag, Warszawa 2006.

Majka P., Człowiek obiecany, Insignis, Kraków 2016.

Shooter J., Zeck M., Layton B., Superbohaterowie Marvela: Tajne Wojny, przeł. J. Drewnowski, Hachette, Warszawa 2013.

Szepty zgładzonych. Opowiadania polskich fanów uniwersum Metro 2033, Insignis, Kraków 2015. Szmidt R.J., Wieża, Insignis, Kraków 2016.

W blasku ognia. Wybór najlepszych opowiadań polskich fanów Uniwersum Metro 2033, Insinis, Kraków 2014.

Węcławek D., Upadła świątynia, Fabryka Słów, Lublin 2016.

\section{Opracowania}

Anusiewicz J., Lingwistyka kulturowa. Zarys problematyki, Wydawnictwo Uniwersytetu Wrocławskiego, Wrocław 1994.

Apanowicz J., Metodologia ogólna, Bernardinum, Gdynia 2002.

Balbus S., Metodologie i mody metodologiczne we wspótczesnej humanistyce (literaturoznawczej), „Przestrzenie Teorii” 2002, nr 1.

Balcerzan E., Sobowtóry i refleksy literackości w uniwersum semiotycznym, [w:] idem, Literackość. Modele, gradacje, eksperymenty, Wydawnictwo Naukowe UMK, Torun 2013.

Balcerzan E., W stronę genologii multimedialnej, „Teksty Drugie” 1999, nr 6.

Bartmiński J., Czym zajmuje się etnolingwistyka, „Akcent” 1986, nr 4.

Bąba S., Trudny orzech do zgryzienia czyli o poprawności frazeologicznej, Wydawnictwo Poznańskie, Poznań 1986.

Bocheński J.M., Wspótczesne metody myślenia, Wydawnictwo WD, Poznań 1992.

Bolter J.D., Grusin R., Remediation: Understanding of New Media, MIT Press, Cambridge 1999.

Burkacka I., Porównawcza analiza gniazdowa wybranych leksemów neutralnych i nacechowanych ekspresywnie, Elipsa, Warszawa 2001.

Burszta W.J., Język a kultura w myśli etnologicznej, PTL, Wrocław 1986.

Burzyńska A., Kulturowy zwrot teorii, [w:] Kulturowa teoria literatury. Główne pojęcia i problemy, red. M.P. Markowski, R. Nycz, Universitas, Kraków 2010.

Charbonnier G., Rozmowy z Claude Lévi-Straussem, przeł. J. Trznadel, Czytelnik, Warszawa 1968.

Compagnon A., Demon teorii. Literatura a zdrowy rozsadek, przeł. T. Stróżyński, słowo/obraz terytoria, Gdańsk 2010.

Feliga P., Czas i ortodoksja. Hermeneutyka teologii w świetle „Prawdy i metody” Hansa-Georga Gadamera, Wydawnictwo UMK, Torun 2014.

Filiciak M., Internet - społeczne metamedium, [w:] Media audiowizualne, red. W. Godzic, Wydawnictwa Akademickie i Profesjonalne, Warszawa 2010.

Foucault M., Słowa i rzeczy, przeł. T. Komendant, słowo/obraz terytoria, Gdańsk 2007.

Furdal A., Językoznawstwo otwarte, Ossolineum, Opole 1977. 
Genette G., Palimpsesty. Literatura drugiego stopnia, przeł. A. Milecki, T. Stróżyński, słowo/obraz terytoria, Gdańsk 2014.

Gontarczyk M., Obama i McCain z mieczami świetlnymi, czyli politycy w dobie kulturowej konwergencji, ,e-Poloitikon” 2013, nr 5.

Greenberg J.H., Rola typologii w rozwoju nauki o języku, przeł. A. Weinsberg, [w:] Językoznawstwo strukturalne. Wybór tekstów, red. H. Kurkowska, A. Weinsberg, PWN, Warszawa 1979.

Greimas A.J., Semantique structurale, Recherche de méthode, Larousse, Paris 1966.

Grochowski M., Strukturalizm i poststrukturalizm w polskim językoznawstwie synchronicznym (refleksje metodologiczne), „Biuletyn Polskiego Towarzystwa Językoznawczego” 2011, z. 67.

Grudzińska K., Rozwój kulturowej teorii języka — od filozofii i etnolingwistyki do dydaktyki, „Episteme. Czasopismo Naukowo-Kulturalne" 1, 2014, nr 23.

Grzmil-Tylutki H., Francuska lingwistyczna teoria dyskursu. Historia, tendencje, perspektywy, Universitas, Kraków 2010.

Hejmej A., Komparatystyka interdyscyplinarna, [w:] Komparatystyka dla humanistów, red. M. Dąbrowski, Wydawnictwo UW, Warszawa 2011.

Hintikka J., Exploring Possible Worlds, [w:] Possible Worlds in Humanities, Arts and Sciences, red. A. Sture, De Gruyter, Berlin-New York 1989.

Hjelmslev L.T., Jazyk, z duńskiego na czeski przeł. M. Dokulil, Academia, Praha 1971.

Hjelmslev L.T., Prolegomena do teorii języka, przeł. H. Kurkowska, A. Weinsberg, [w:] Językoznawstwo strukturalne. Antologia tekstów, red. H. Kurkowska, A. Weinsberg, PWN, Warszawa 1979.

Hjelmslev L.T., Sproget. Ein Introduktion, Berligske Forlag 1963.

Hubner I., Semiotyka a literatura i literaturoznawstwo, „Acta Universitatis Lodzendzis. Folia Litteraria Polonica" 2005, nr 7.

Jadacka H., Opis gniazdowy jako podstawa badania łączliwości formantów, „Prace Filologiczne” 43, 1998.

Jenkins H., Kultura konwergencji. Zderzenie starych i nowych mediów, przeł. M. Bernatowicz, M. Filiciak, Wydawnictwa Akademickie i Profesjonalne, Warszawa 2007.

Kay A., Goldberg A., Personal Dynamic Media, „Computer” 1977, nr 3.

Kegan Y., Subgenres of the Beast. A Heavy Metal Guide, Lulu.com, [b.m.w.] 2015, hasło: Neue Deutsche Härte.

Kinder M., Playing with Power in Movies, Television, and Video games. From Muppet Babies to Teenage Mutant Ninja Turtles, University of California Press, Berkeley 1993.

Krupińska E., Czy Hjelmsleva można zastosować w muzykologii? Substancjalno-formalna analiza dzieła muzycznego - preliminaria, „Res Facta Nova” 2012, nr 13.

Krupińska E., Jak Hjelmsleva można zastosować w muzykologii? Analiza substancjalno-formalna dzieła operowego na przyktadzie opery „,Faustus, the Last Night” (2003-2004) Pascala Dusapina, „Res Facta Nova” 2013, nr 14.

Lichański J.Z., ,,Niobe” Konstantego Ildefonsa Gałczyńskiego, Universitas, Kraków 2015.

Linde-Usiekniewicz J., Semantyka strukturalna w XXI wieku?, [w:] Metodologie językoznawstwa. Współczesne tendencje i kontrowersje, red. P. Stalmaszczyk, Lexis, Kraków 2008.

Lindke S., Der Tabubruch von heute ist der Mainstream von morgen - Die »Neue Deutsche Härte als ästhetisches Spiegelbild der wiedererstarkten Nation, [w:] Ästhetische Mobilmachung. Dark Wave, Neofolk und Industrial im Spannungsfeld rechter Ideologien, red. A. Speit, Unrast, Hamburg-Münster 2002.

Lisowska-Magdziarz M., Bunt na sprzedaż. Przemyst muzyczny - reklama - semiotyka, Wydawnictwo UJ, Kraków 2000.

Łachnik J., Podstawy metodologiczne gniazdowego opisu złożeń i ich roli w systemie słowotwórczym polszczyzny, „LingVaria” 2009, nr 1.

Łotman J., Kultura i eksplozja, przeł. B.Żyłko, PIW, Warszawa 1999.

Literatura i Kultura Popularna 24, 2018

(C) for this edition by CNS 
Łotman J., O znaczeniach we wtórnych systemach modelujących, przeł. J. Faryno, „Pamiętnik Literacki" 1969 , z. 1.

Łotman J., Semiotyka filmu, przeł. J. Faryno, T. Miczka, Wiedza Powszechna, Warszawa 1983.

Łotman J., Szuka jako język, [w:] idem, Struktura tekstu artystycznego, przeł. A. Tanalska, PIW, Warszawa 1984.

Łotman J., Uspieński B., O semiotycznym mechanizmie kultury, przeł. J. Faryno, [w:] Semiotyka kultury, wyb. E. Janus, M.R. Mayenowa, PIW, Warszawa 1977.

Monroe-Cassel C., Lehrer S., Uczta lodu i ognia, przeł. Ł. Małecki, Wydawnictwo Literackie, Kraków 2013.

Morawski S., Estetyka a semiotyka, „Pamiętnik Literacki” 1976, z. 3.

Natoli J., Introduction, [w:]: Tracing Literary Theory, red. J. Natoli, University of Illinois Press, Urbana 1987.

Nelson C., Treichler P.A., Grossberg L., Cultural Studies: An Introduction, [w:] Cultural Studies, red. C. Nelson, P.A. Treichler, L. Grossberg, Routledge, New York 2013.

Nowak T., Język w świetle odkryć nauki, Wydawnictwo Petrus, Kraków 2011.

Olejniczak M., 30 lat językoznawstwa gniazdowego (rys historyczny), [w:] Stowotwórstwo gniazdowe. Historia. Metoda. Zastosowania, red. M. Skarżyński, Księgarnia Akademicka, Kraków 2003.

Ossowska M., Ossowski S., Nauka o nauce, „Nauka Polska” 1935, nr 20.

Pawłowski A., Struktura ilościowa pól leksykalnych a procesy poznawcze człowieka, „Studia Semiotyczne" 27, Warszawa 2010.

Pilszczikow I., Dziedzictwo rosyjskiej szkoły formalnej. OPOJAZ i Moskiewskie Koło Lingwistyczne a wspótczesna filologia, przeł. A. Berkieta, „Przestrzenie Teorii” 2011, nr 16.

Rosner K., A.J. Greimasa semiotyka narracji, „Pamiętnik Literacki” 1976, z. 2.

Rosner K., Semiotyka strukturalna w badaniach nad literatura, Wydawnictwo Literackie, Kraków 1981.

Satkiewicz H., Produktywne typy słowotwórcze współczesnego języka polskiego, Wydawnictwo UW, Warszawa 1969.

Saussure de F., Kurs językoznawstwa ogólnego, przeł. K. Kasprzyk, Wydawnictwo Naukowe PWN, Warszawa 2002.

Shooter J., Zeck M., Layton B., Superbohaterowie Marvela: Tajne Wojny, przeł. J. Drewnowski, Hachette, Warszawa 2013.

Sitarski P., Obcość i dekoracje w systemie rozrywkowym „,Blade Runner”, [w:] Wokól gotycyzmów, red. G. Gazda, A. Izdebska, J. Płuciennik, Universitas, Kraków 2002.

Skarżyński M., Stan obecny i perspektywy słowotwórstwa synchronicznego, [w:] Collectanea linguistica in honorem Casimiri Polański, red. M. Brzezina, H. Kurek, Księgarnia Akademicka, Kraków 1999.

Skarżyński M., Wstęp, [w]: Stowotwórstwo gniazdowe. Historia, metoda, zastosowania, red. M. Skarżyński, Księgarnia Akademicka, Kraków 2003.

Skrzypek L., Humanista w poszukiwaniu metody, „Scripta Comeniana Lesnensia” 2008, nr 6.

Stachak S., Wstęp do metodologii nauk ekonomicznych, Książka i Wiedza, Warszawa 1997.

Szaumian S.K., Strukturnaja lingwistyka, Nauka, Moskwa 1965.

Uspienski B., Strukturalna wspólnota różnych rodzajów sztuki (na przykładzie malarstwa i literatury), przeł. Z. Zaron, [w:] Semiotyka kultury, wyb. E. Janus, M.R. Mayenowa, PIW, Warszawa 1977.

Walczak B., Literatura piękna jako źródło do badań z zakresu socjolingwistyki historycznej, „Annales Universitatis Paedagogicae Cracoviensis. Studia Linguistica” 2013, nr 8.

Wałaszewski Z., Wiedźmin: pierwszy polski supersystem rozrywkowy, [w:] Obraz literatury w komunikacji spolecznej po roku'89, red. A. Werner, T. Żukowski, Warszawa 2013. 
Warchala J., Kategoria potoczności w języku, Wydawnictwo Uniwersytetu Śląskiego, Katowice 2003.

Wąsik Z., Semiotyczny paradygmat językoznawstwa. Z zagadnień metodologicznego statusu lingwistycznych teorii znaku i znaczenia, Wydawnictwo Uniwersytetu Wrocławskiego, Wrocław 1987.

Weinsberg A., Językoznawstwo ogólne, PWN, Warszawa 1983.

Wołowska K., Czy analiza składnikowa jest metoda przestarzałą? Rozwój badań nad struktura semantyczna jednostek leksykalnych we współczesnym językoznawstwie francuskim, „Linguistica Copernicana" 2010, nr 1.

Zariecki W.A., Obraz jako informacja, przeł. L. Suchanek, „Pamiętnik Literacki” 1969, z. 1.

Zeszyt próbny słownika gniazd słowotwórczych wspótczesnego języka ogólnopolskiego, oprac. H. Jadacka, Wydawnictwo UW, Warszawa 1988.

\section{Źródla internetowe}

Nowa Huta schronpodkinem Światowid, 17.11.2013, https://www.youtube.com/watch?v=m73uilkM18g.

Seria Fallout - seria gier, „GRYOnline.pl”, http:/www.gry-online.pl/gry-z-serii-i-podobne.asp? $\mathrm{ID}=22$.

Banaś M., Transgresja i dyfuzja - czyli o tym, dlaczego nauki społeczne i humanistyczne sięgają do terminologii nauk przyrodniczych, „Kultura-Historia-Globalizacja” 2013, nr 14, http://www. khg.uni.wroc.pl/files/1_\%20KHG_14_banas_t.pdf.

GhostWriter [właśc. ?], temat: Metro 2035-opinie!, 27.11.2015, http://metro2033.pl/phpbb/viewtopic.php? $\mathrm{f}=54 \& \mathrm{t}=20956 \&$ start $=25$.

http://www.hack.channel.or.jp.

Krakus [właśc. ?], Podziemia Nowej Huty, „forgotten.places”, 13.11.2011, http://www.forgotten.pl/ miejsce.php?id=684.

Lady Werewolf [właśc. ?], Metro 2035 - Dmitry Glukhovsky (recenzja przedpremierowa), „Kawerna.pl”, 29.10.2015, http://www.kawerna.pl/recenzje/ksiazka/item/10829-metro-2035-dmitry-glukhovsky-recenzja-przedpremierowa.html.

Mazurkiewicz A., Pozycja osobna [rec. D. Głuchowski, Metro 2035], „Creatio Fantastica” 2015, $\mathrm{nr}$ 4, https://creatiofantastica.files.wordpress.com/2015/12/rec-adam-mazurkiewicz-pozycja-osobna.pdf.

Metro 2033: Last Hope — Live Action, Polska, reż. P. Kwidzynski et al., 2014, https://www.youtube. $\mathrm{com} /$ watch? $=8 \mathrm{D}-\mathrm{vH} 4 \mathrm{cPXtg}$.

Palij S., Bezymianka, przeł. B.T. Banach, P. Norberciak, 2017, https://www.dropbox.com/s/ hl3obq1lqb0k9z7/Bezymianka.pdf?dl=0.

Radłowska R., Schrony i miejsca ukrycia, czyli nowohuckie osobliwości, „Gazeta Wyborcza” 25.11. 2014, http://krakow.wyborcza.pl/krakow/1,44425,17022114,Schrony_i_miejsca_ukrycia_czyli_nowohuckie_osobliwosci.html?disableRedirects=true.

Trembicka-Brzozowska D., I bez wrogów sobie radzimy [rec. D. Głuchowski, Metro 2035], „Gildia. pl”, 10.02.2016, http://www.literatura.gildia.pl/tworcy/dmitry-glukhovsky/metro-2035/recenzja.

\section{Filmografia}

Ghost in the Shell: Stand Alone Complex, reż. K. Kamiyama, Japonia 2002-2005.

Ludzkie dzieci, reż. A. Cuarón, USA-Wielka Brytania 2006. 


\title{
On the (possible) analysis of the entertainment super- system from the perspective of employing selected achievements of linguistics: A methodological approach
}

\begin{abstract}
Summary
Currently linguistics treats the subject of its study not so much as a tool for social communication, but as an integral element of culture. At the same time, culture is perceived as a system of symbolic meanings. However, the same position is occupied by "entertainment supersystems" whose role is transmedia storytelling. From the perspective of semiotics they are - just as the language system - a sign. Thus, perhaps employing the descriptive instrumentarium of language mechanisms, due to its peculiar character, will allow for a more adequate consideration of cultural phenomena (in this case the entertainment supersystem) than applying this methodology outside humanities. What is more, a transfer of focus from an ontological perspective (seeking to answer the question of what an entertainment supersystem is or is not) to an epistemological one (an attempt to understand how it functions in society, that is, "how it is used") seems to be compliant with the transition from linguistic structuralism to the post-structuralistic paradigm. At the same time, considering methodological implications which derive from the analysis of mechanisms regulating the functioning of entertainment supersystems by means typical for the linguistics instrumentarium, one can easily reach the conviction that text as an object of study has been reinstated in its central position.
\end{abstract}

